Portland State University

PDXScholar

1983

\title{
Life satisfaction of elderly parents and parent-child relationships in old age
}

Tehchou Yeh

Portland State University

Follow this and additional works at: https://pdxscholar.library.pdx.edu/open_access_etds

Part of the Family, Life Course, and Society Commons, and the Gerontology Commons Let us know how access to this document benefits you.

\section{Recommended Citation}

Yeh, Tehchou, "Life satisfaction of elderly parents and parent-child relationships in old age" (1983). Dissertations and Theses. Paper 3278.

https://doi.org/10.15760/etd.3269

This Thesis is brought to you for free and open access. It has been accepted for inclusion in Dissertations and Theses by an authorized administrator of PDXScholar. Please contact us if we can make this document more accessible: pdxscholar@pdx.edu. 
AN ABSTRACT OF THE THESIS OF Tehchou Yeh for the Master of Science in Sociology presented May 20, 1983.

Title: Life Satisfaction of Elderly Parents and Parent-child Relationships in 01d Age.

APPROVED BY MEMBERS OF THE THESIS COMMITTEE:

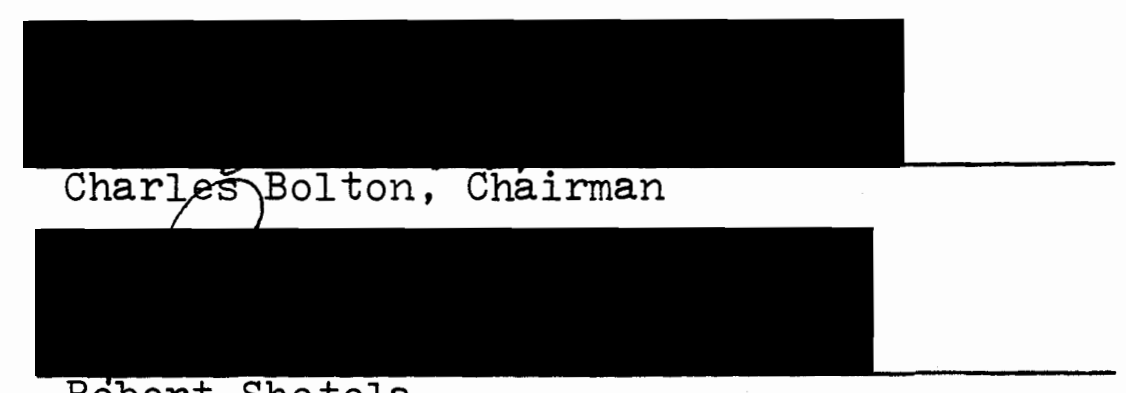

Róbert Shotola

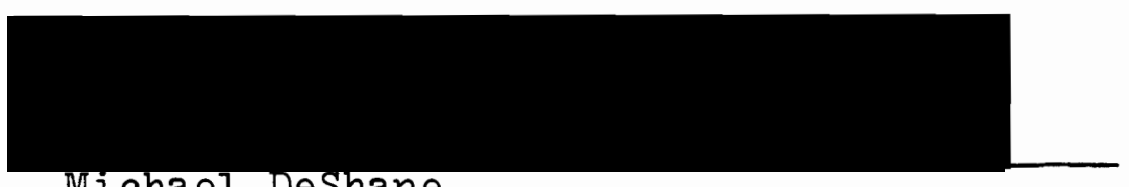

Wichael Deshane

This thesis is designed to explore the nature of the relationship between elderly parents and their children and to investigate the association of that relationship with life satisfaction of the elderly parents. The examination of parents' life satisfaction is based on the activity theory of gerontology. The life satisfaction is measured by Adams's eighteen-item Life Satisfaction Index. The parent-child relationship is viewed from the standpoint of both the parents' expectations of their children and how the children 
fulfill these expectations. Filial discrepancies between parents' expectations and children's behavior are analyzed to fill a gap in the literature on behavioral and normative comparisons in generational relations.

The sample for this research was collected from three senior citizen centers in the city of Portland, Oregon. The findings show that these elderly parents' life satisfaction has a negative association with their expectations of their children, but a positive association with their children's filial behavior; and if children's filial behavior towards their parents exceeds their parents' expectations, the parents will have more satisfaction in their lives than those parents whose expectations of their children exceed their children's actual behavior towards them.

The data analysis indicates that children's filial behavior is the most influential variable affecting not only their parents' life satisfaction but also the relationships between life satisfaction and filial discrepancies. Thus, adult children are still important in their parents' late Iives.

Finally, this thesis tends to support the activity theory, since the data demonstrate that the more the filial involvement of children with their parents, the higher the Iife satisfaction for the parents. 
LIFE SATISFACTION OF ELDERLY PARENTS

AND PARENT-CHILD RELATIONSHIPS IN OLD AGE

\author{
by \\ TEHCHOU YEH
}

A thesis submitted in partial fulfillment of the requirements for the degree of

\author{
MASTER OF SCIENCE \\ in \\ SOCIOLOGY
}

Portland State University

1983 


\section{TO THE OFFICE OF GRADUATE STUDIES AND RESEARCH:}

The members of the Committee approve the thesis of Tehchou Yeh presented May 20, 1983.
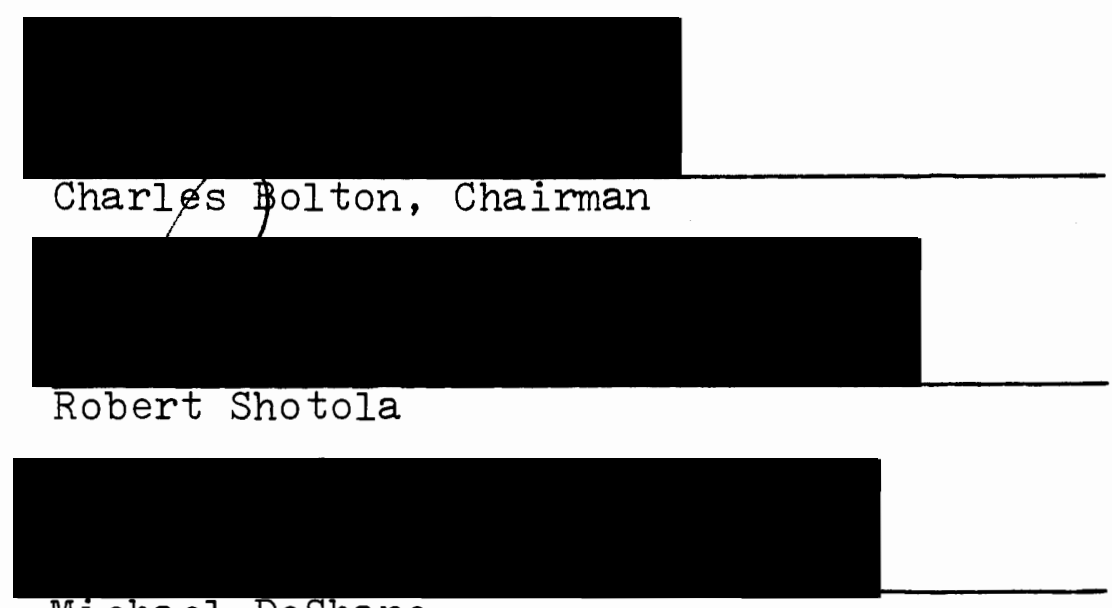

VII chael Deshane

\section{APPROVED :}
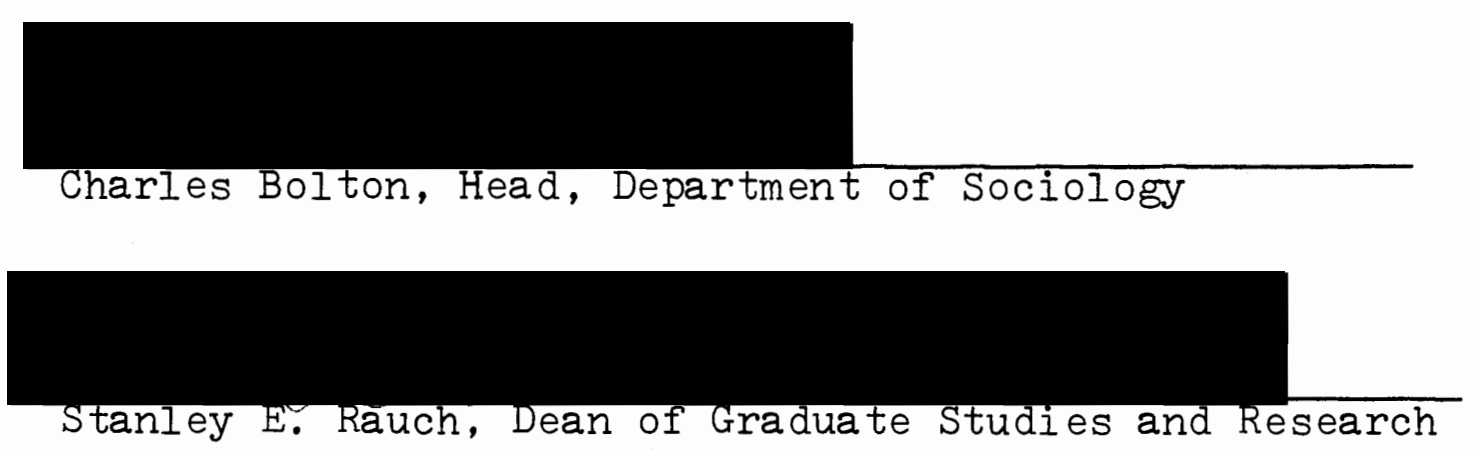
ACKNOWLEDGENENT

On completion of this thesis, I would like to gratefully acknowledge the help, time, and involvement given to me by members of my thesis committee. I would like to thank Dr. Charles Bolton for his comments on the thoughts and writing, Dr. Robert Shotola for his assistance on the interpretation of statistics results, and Dr. Michael DeShane for his suggestions on both the fields of aging and the family.

I want to express my appreciation to those ladies who are in charge of the senior citizen centers, who helped me in conducting the survey and distributing the questionnaires. I also want to thank the people who took time to respond to the questionnaire.

I wish to thank Mr. Jim Wilson, for spending hours patiently correcting my writing style. I am also grateful to Dr. Leonard Cain for his concerns and encouragement, and to Mrs. Mary Foon for her advice on typing this manuscript. Finally, my appreciation to my family is beyond expression. For years, they have supported me spiritually and financially. My appreciation especially goes to my 72 year old father for his love and understanding. This thesis was written with him in my mind and is dedicated to him. 
TABLE OF CONTENTS

PAGE

ACKNOWLEDGENENTS . . . . . . . . . . . .

LIST OF TABLES .............. . . . . vi

CHAPTER

I INTRODUCTION ................... 1

II REVIEW OF LITERATURE . . . . . . . . 5

Perspectives on Aging . . . . . . 5

Generational Perspectives...... 12

III METHODOLOGY . . . . . . . . 27

Dependent Variable . . . . . . 27

Independent Variables . . . . . . . 29

Hypotheses ........... 31

Instruments . . . . . . . . 33

Data Gathering Procedure ...... 37

The Sample . . . . . . . . . 39

Data Analysis............ 40

IV RESULTS ............... 43

Characteristics of the Instruments .. . 43

Characteristics of the Respondent . . 48

Hypotheses ............ 66

V DISCUSSION AND CONCLUSION . . . . . . 84 
A SELECTED BIBLIOGRAPHY • • . . . . . . . . . . . 91 APPENDIX A . . . . . . . . . . . . . . . . 97 APPENDIX B . . . . . . . . . . . . . . 102 APPENDIX C . . . . . . . . . . . . . . . 104 APPENDIX D .................. 105 


\section{LIST OF TABLES}

TABLE

PAGE

I Living Arrangement by Marital Status . . . . 48

II Correlations Among Activity Variables . • . 49

II Levels of Social Activity . . . . . . . . 50

IV Relationship Between Age and the Level

of Activity . . . . . . . . . . . 50

V Responses with Iife Satisfaction Index . . . 53

VI Agreements with Filial Expectation Index . . 55

VII (A) The Distribution of Children's Living Arrangements . . . . . . . . . . . . 57

VII (B) Living Areas of the Children . . . . . . 58

VIII Children's Assistance to Parents . . . . . . 58

IX Contact of Children with Parents . . . . . . 60

X Parents' Judgements on Children's Attitudes,

Conformity, And Responsibility . . . . . . 61

XI Levels of Life Satisfaction, Filial Expectation, And Filial Behavior . . . . . . . . 63

XII Filial Discrepancies (FB-FE) . . . . . . . . 64

XIII Correlations of Life Satisfaction with Items

In Respondents' Backgrounds, Filial Expectations, And Filial Behavior . . . . . . . . . 67 
TABLE

XIV Correlations of Life Satisfaction with Filial

Expectations, Filial Behavior, and Filial

Discrepancies . . . . . . . . . 69

XV Partial Correlations Among Major Variables • 72

XVI Correlations of Respondents' Backgrounds with

Filial Expectations, Filial Behavior, and

Filial Discrepancies . . . . . . . . . 74

XVII Zero-order and First-order Partial

Correlations . . . . . . . . . . 79 
CHAPTER I

INTRODUCTION

How to achieve successful aging has long been of concern to social gerontologists. There are two major theories in the literature seeking to explain successful aging: activity theory and disengagement theory. Life satisfaction is the term most commonly used to denote successful aging as viewed from the standpoint of an individual's inner satisfaction with his or her past or present life. Research indicates that there is a significant relationship between social activities and life satisfaction. However, the two major gerontological theories consider different kinds of social activities to be crucial for successful aging. Activity theory holds that aging is apt to be most successful when the aging individual continues his or her involvement in many of the kinds of activies engaged in during the years of middle age: work activities, family activities, sociability with persons of varying ages, etc. Disengagement theory argues that, because disengagement from mainstream society is functional for both the elderly person and the rest of society, the older person ages most successfully when he or she withdraws from the work world and from the conventional interaction patterns of middle age and focuses instead on inter- 
action with other older persons and on more passive inwardturning activities.

The problem of testing the relative validity of these two theories is that, if behavioral indexes are used for successful aging, each theory is somewhat tautological and hence untestable. That is, activity theory tends to measure success in aging by the same variables--continued involvement in the activities of middle-age--that are asserted to cause successful aging; while disengagement theory tends to measure successful aging by the very forms of withdrawal from mainstream society that are asserted to be necessary to successful aging. To be sure, in some studies the problem of tautology is avoided by the use of such indexes as death rate, illness rate, and degree of senility as the dependent variable in testing the relative validity of the two theories. But in the theoretical formulations themselves there remains a serious problem of tautological propositions.

In the present study, life satisfaction, as measured by responses to a scale of questions about subjective selffeelings, is used as the index for successful aging.

One aspect of social activities, the relationship of elderly parents with their adult children, is examined as an independent variable. The family system is still considered a crucial institution for continuing social activity among elderly people. In a rapidly changing society, the family has become more important, not less important to the indi- 
vidual (Shanas and Streib, 1965). A basic family relationship is that between parents and their offspring. Parents and children play reciprocal roles. Parents are obliged to raise their children, an important task that involves their middle lives. Children expect their parents to provide them with basic care. As parents get older, children who received care from their parents in childhood are obligated in return to provide for the needs of their aging parents. Parents have served their children throughout life and they can count on the children especially in time of need (Peterson, 1979). Thus, normatively, older parents expect and their grown offspring are obliged to fulfill the parents' expectations.

The purpose of this study is to investigate the association between life satisfaction among elderly parents and the relationships of parents with their adult children. This study will search for an answer to the question: what kind of parent-child relationships in old age will enhance parents' life satisfaction?

The parent-child relationship in old age--PCR--has previously been studied primarily from the standpoint of actual practice of interactions between the generations. This study will view PCR taking into account both the parents' expectations and how adult children fulfill those expectations.

There are ordinarily discrepancies between normative expectations and actual behavioral practice. In the fol- 
lowing pages a new term, "filial discrepancies," will be utilized to fill a gap in the literature on behavioral and normative comparisons in generational relationships and to allow a more complete characterization of PCR. This study will further examine whether disengagement theory or activity theory is the more applicable in studying successful aging and the old-parent-adult-child relationship. 
REVIEW OF LITERATURE

Two central perspectives have been utilized to account for the relation between life satisfaction in later life and older parent-adult child relationships. The first perspective attempts to explain life satisfaction through an understanding of the aging process. Work on the development of theories of successful aging and studies regarding correlates of life satisfaction are examples of this perspective. The second perspective has approached this relation through the development of generational theories. Examples of the generational perspective are studies in the interaction between parents and children of old age.

\section{PERSPECTIVES ON AGING}

Cavan, Burgess, Havighurst, and Goldhamer published Personal Adjustment in 01d Age in 1949. Known as a pioneer work of activity theory, this book was the first sociological approach to successful aging. This approach developed the concept of personal adjustment. To measure the adjustment, the authors designed two inventories: namely, attitudes and activity. These inventories sought to measure a person's attidues expressing satisfaction or dissatisfaction with his 
life situations and the degree of his participation in daily activities (Cavan et al., 1949). The focus of their analysis of adjustment was entirely on overt activity. The authors noticed the importance of family activities for adjustement to old age, and suggested that participation in varied activities is a crucial factor for personal adjustment in later life.

The activity approach was later to be refined into activity theory. According to this theory, to age successfully a person must continue to be involved in an activity pattern similar to that of his adult working years and must continue to maintain values like those of his middle age. Therefore, successful aging is seen as a conscious effort to maintain a continuation of middle-age activities and values into old age.

In 1955, six years after the publication of Personal Adjustment in 0ld Age, another research group set up a study of the aging process. This study, known as the Kansas City Study of Adult Life, started with a commonsense observation that "the old person is less involved in the life around him than he was when he was younger." The study ended with disengagement theory, which argues that aging is an unavoidable withdrawal of the aging individual from the social and economic responsibilities of middle age, "resulting in decreased interaction between the aging persons and others in the social systems he belongs to" (Cumming and Henry, 1961, p.14). 
The theory proposed that this withdrawal from social interaction will cause the aging person to have a higher morale level. In other words, it is inappropriate for people to still hold onto middle-age activity patterns and values in later years; doing so will result in a loss of morale. The "disengagement" research group developed two measurements to determine a formula for successful aging. One measures engagement. The other measures morale.

The major theme of this theory holds that disengagement can be viewed as a mechanism for reducing intergenerational conflict. If disengagement is defined in terms of the social structural level, such as withdrawal from the extended family, the logic is clear. If social systems are to maintain equilibrium, they must disengage from the elderly. For instance, if equilibrium within a family is to be maintained, the older people have to abandon authority as the younger one are ready for it. Thus, disengagement is a functional prerequisite to social stability.

At about the same time, another research group claimed that neither activity theory nor disengagement theory was adequate to account for the various aging process. Because aging is a complex phenomenon, older people do not comprise a homogeneous group, especially in terms of their internal psychological states. Research indicated that the most important source of an individual's well-being in old age is his feelings and his attitudes about himself. This is the 
Iife satisfaction approach, which assumes that people have aged successfully if they feel happy and are satisfied with their present and past lives (Neugarten, Havighurst, and Tobin, 1961).

The uniqueness of this approach was that it defined successful aging in terms of inner satisfaction rather than of external adjustment. Although this approach never developed into a theoretical formula, it devised three useful measures for determining successful aging. One of the measures, Life Satisfaction Index A, became the most representative instrument for testing either the activity theory or the disengagement theory. Thereafter, several studies used Index $A$ as an indicator of psychological well-being or adjustment in later life.

In the present study, the term "life satisfaction" will be used to indicate the quality or condition of aging. Iife satisfaction is based on an individual's own evaluation of his or her present and past Iife. As George and Bearon suggested, popularity probably is an indication of usefulness of a concept. The term "Iife satisfaction" is definitely an example. "Gerontologists persistently use it as a criterion for successful aging" (George and Bearon, 1980, p.42). The term has a wide and varied usage, referring to non-specific Iife conditions such as "life as a whole" or "life in general."

In short, activity theory and disengagement theory ask 
similar questions to measure a person's participation in activities, and use a similar instrument to measure his or her psychological well-being (in their respective terms "satisfaction in Iife" or "morale") in order to determine whether the person is aging successfully. Although the two theories suggest an appropriate way to adjustment in later life from opposite directions, both theories can correctly describe certain aspects of the social-psychological process of aging. As the life satisfaction approach suggested, aging is a complex phenomenon; older people comprise a heterogeneous group.

Furthermore, disengagement theory concedes that social participation is associated with life satisfaction; while activity theory accepts that there is a decrease in overall social activity with age. The disagreement between them is only on the degree and to some extent form of relationship between activity and satisfaction in successful aging. Several studies are examples of this:

Tobin and Neugarten (1961) found that a high level of life satisfaction occurred more often with persons who were inactive and uninvolved. Moreover, their findings showed that with advancing age, engagement, rather than disengagement, was more closely associated with life satisfaction.

Supporting disengagement theory, Maddox found that activity tends to decrease as age increases. However, he concluded that there was also a positive relationship between 
activity and morale (Maddox, 1962; 1963). Lowenthal and Boler (1965) conducted a study not specifically designed to test any theory, but their findings indirectly sustained the disengagement theory.

Martin (1973) agreed with both theories. He found that both patterns--engagement and disengagement--could happen, and both would result in satisfaction in life. Yet, his discussion indicated that two major institutions in American society, the family and the economy, encouraged mutual disengagement.

At any rate, since these two prevailing and contrasting theories appeared in the field of aging, the significance of activity participation for life satisfaction in old age has been a focus of attention.

Despite the fact that research has produced mixed findings about the importance of social activities for the life satisfaction of older people, family interactions have always been considered one of the major social activities for the elderly (Adams, 1971; Bell, 1967; Conner et al., 1979; Edwards and Klemmack, 1973; Graney, 1975; Lemon et al., 1972; Lowenthal and Bolder, 1965; Medley, 1976; Preston, 1966; Rubenstein, 1971). Only a little research does not include family interaction as a variable correlated with life satisfaction (Larson, 1978; Markides and Martin, 1978; Palmore and Luikart, 1972; Spreitzer and Snyder, 1974). This oversight can be interpreted as meaning that people take familial asso- 
ciation for granted: familial influence on satisfaction in old age cannot be denied (Adams, 1971 ).

Family relations and life satisfaction among the aged have been shown to be positively associated. In a study among residents in homes for the aged, Bell (1967) found that the frequency of family interaction strongly influenced a person's self-perception of being old: "feeling old" was associated with low family interaction, whereas not feeling old tended to be associated with high family interaction. Feeling old was seen as part of the total process of disengagement. Among the categories of social involvement, family involvement had the most significant relationship with selfperception of being old.

One exploration of activity theory found that interactions with relatives were associated with life satisfaction, but the association was not significant (Lemon et al., 1972). On the other hand, after examining several correlates with life satisfaction from previous studies, Medley (1976) concluded that satisfaction with family life constituted the greatest single influence on positive satisfaction with life as a whole.

In another investigation, Conner and his colleagues synthesized four groupings from the twenty-two quantitative measures of social interaction significantly associated with life satisfaction. One of these four measures was the number of immediate family members seen. Their work not only recog- 
nized the importance of family interactions to the psychological well-being of the elderly, but also questioned the typical emphasis on the quantity--frequency and scope--of the interaction. They were more concerned about the "quality" of the interaction, in other words, whether the interaction with the family members would meet the elderly's personal needs (Conner et al., 1979).

Nevertheless, none of the above studies indicated specific family members as having crucial roles in the family contact which correlate with life satisfaction for older persons. From the data, Rubenstein (1971) pointed out that elderly persons living alone or without a spouse had a low state of morale in old age. The same result was also found in other research (Lee, 1978; Riley and Foner, 1968).

\section{GENERATIONAL PERSPECTIVES}

Besides the influence of spouse, what is known with respect to the associations between life satisfaction and family relationships among the aged, such as older parentsadult children interaction? Studies are meager regarding the effect of interaction with adult children on the life satisfaction of older parents. Moreover, it is surprising to learn that most research in this area has found no correlation between life satisfaction of the elderly and their contact with their adult children.

Arling (1976) compared family involvement with friend- 
ship and neighboring to see which had a greater impact on the personal morale of elderly widows. The result was that contact with family members, especially with children, did little to elevate morale. No relationships between morale and older parent-adult child exchange of aid were found from a sample of 403 parents aged 60 and over (Lee and Ellithorpe, $1982)$.

In other studies, there was found to be an association between increased parent-child interactions and decreased morale of aging parents. It was reported that parents who had lower levels of mutual support activities with their adult children had higher morale. Also, parents who made fewer demands on their offspring had higher morale. It may be that dependency on the next generation for living arrangements, and propinquity of offspring, contributed to unhappiness in late life. Therefore, the farther away the two generations live from each other and the less supportive the contact between them, the higher the morale of the parents (Kerckhoff, 1966; Watson and Kivett, 1976).

In addition to the interaction between the two generations, the expectations which older parents had regarding the obligations of their offspring were also found to be inversely related to morale among the aged. It was found from data of nearly six hundred elderly parents 65 years of older that those parents who expressed high expectations of their offspring exhibited low morale, whereas those with low expecta- 
tions show high morale (Seelbach and Sauer, 1977).

The evidence is inconsistent as to the contribution of children to parental feelings of satisfaction in late life. Two studies reached different conclusions from the studies reviewed above. However, they are incomplete in this area in that they neglect some aspect of parent-child interaction.

In the first study, Rosow (1965) concluded from a comparison that children are more important to older people than are friends. The elderly used friends or neighbors as alternatives to children only within the context of social activity. Parent-child relationships could not be substituted for or replaced by friendship. But Rosow did not make clear exactly what the meaning of "importance of children" was to their aging parents.

Backman and Houser (1982) supported the societal perception that childlessness has a greater effect on well-being for the widowed than for married women. Even when other crucial factors were considered, childless widows had lower overall well-being and were more lonely and dissatisfied with their lives than were widows with grown children. Yet, this study failed to further investigate the quality of the relationships between these widowed mothers and their adult offspring.

There are some implications behind those studies which found an inverse association, or failed to establish an association, between parents' life satisfaction and parent-child 
interaction. First, although these family sociologists did not intend to test disengagement theory in the gerontological context, it appears they assumed that disengagement is the most applicable theory to aging parents in the generational relations study. As this theory has suggested, the aged who disengage from social systems are supposed to have a higher level of morale. ${ }^{1}$ Second, American elderly parents would seem to be better off if they are physically and spiritually isolated from their adult children. None of these studies explicitly expressed it this way, but they collectively pointed strongly in this direction. If the second implication is correct, then this isolated-elderly-parent phenomonon seems to be consistent with Parsons's theory of the isolated nuclear family.

The American family has been characterized by Parsons as being isolated and nuclear, in terms of residential and economic isolation from intergenerational and bilateral kinship ties. For Parsons, this form of family is the most functional in meeting the requirements of a modern industrial society, which demands a high level of mobility (Christensen, $1964)$.

${ }^{1}$ Cumming and Henry (1961) proposed that there was a steady dimimution in interaction with age as the individual disengaged himself from society. However, it was apparent that the aging person did not withdraw from intimate kin. It was found that children or substitutes for them (nephews, nieces, etc.) were the group with whom these older people felt most engaged at the end of life. This is inconsistent with Cumming and Henry's major propositions. 
Besides Parsons's theory, social norms or expectations in American society regarding parent-child relations, which place so much emphasis on the independence of both generations, are also consistent with the aforementioned studies. Adult children are expected to be economically independent by means of their own efforts, since dependence upon parents is regarded as evidence of weakness or incompetence. Older parents are also supposed to be independent in order to avoid being a burden to their adult or married children. The Parsonian perspective on family and social expectations of independence has been challenged by some family sociologists. 2 They contended that this theory of isolation of family and independence of generation can easily lead people to be under a misapprehension that parent-child relationships in later life are attenuated, or that older parents are rejected by or alienated from their grown children. Shanas (1979a) referred to this phenomenon as "the myth of alienation." She enumerated two facts to question the validity of this myth.

One fact was that even though there was great geographic mobility of the population in this country and even

2 Parsons's theory has been misinterpreted by some family sociologists. For Parsons, isolation does not necessarily mean that there is no contact among relatives at all. Indeed, interchanges of aid exist between children's families and their parents' families. This mutual help is just "clearly subordinated to the need of maintaining the autonomy and self-respect of the recipient families" (Christensen, 1964). 
though old people lived apart from their children or lived alone, the overwhelming majority of them lived within thirty minutes distance from at least one of their children. They often saw their offspring. The other fact was that the existence of large human service bureaucracies did not devalue the importance of family as a major source of care for older parent (Shanas, 1979a). Especially in times of illness, old people would turn first to their immediate family for help, i.e. spouse or offspring (Shanas, 1979b). Therefore, though most old people tried to avoid being a burden on their offspring, it was primarily their children to whom they turned when in need of general assitance, and particularly in times of crisis (Cicirelli, 1981; Riley and Foner, 1968; Robinson and Thurnher, 1979; Sussman, 1965; Troll, 1971). Adult offspring in Simos's study were also greatly involved in helping their parents cope with various problems (Simos, 1973).

other findings further showed that there had been more mutual help activities between the two generations than the norms indicated (Maddox, 1973; Riley and Foner, 1968; Sussman, 1953, 1965, 1970; Sussman and Burchinal, 1968; Streib, 1965). Exchange of assistance was generally quite reciprocal. While financial aid tended to flow from parents to children, with such aid parents tended to expect more affectional response from their children (Sussman, 1965; Sussman and Burchinal, 1968; Streib, 1965).

Notwithstanding that industrialization and urbanization 
made the family change from the traditional extended model to the modern nuclear model, most family sociologists recognize the existence of a new family structure: the modified extended nuclear family. That is, older parents and their adult or married children do not share the same household, but they do maintain contact through an interchange of visits or assistance (Johnson and Bursk, 1977; Kerckhoff, 1965; Shanas, 1973; Streib, 1970).

These works that challenge Parsons's theory of the isolated nuclear family indicate that older American parents are not rejected by or alienated from their adult children. Neither parents nor children are as isolated or independent from each other as Parsons thought and as the norms indicated. 3

If the idea that grown children reject their older parents has been labeled a myth, the opposite belief, that adult children are willing to provide adequate and effective help to their aging parents, may also be considered as a new myth (Cicirelli, 1981). According to the new myth of filial

3 Nonetheless, studies have shown that elderly parents prefer to be independent as long as they can still manage for themselves (Cicirelli, 1981; Kalish, 1967). Because of this desire to remain independent, parent have low expectations of assistance from their children, especially monetary assistance (Watson and Kivetti, 1976). People in Kerckhoff's (1965) study impressively supported the norm of nuclear family independence, even there was an extensive amount of mutual support between generations. This indication clearly shows that "independence is the desired state, if conditions permit" (Kerckhoff, 1965). 
responsibility, there is a duty exercised by adult children toward their old parents, usually connected with protection, care, or financial support (Schorr, 1960).

One essay pointed out that Americans place high value on responsibility to their spouses and to the next generation, but they put little value on the responsibility of adult children to their aging parents. Thus, the parents give and the children receive. This giving is continued to the children's offspring instead of turning back to the parents (Kalish, 1967).

Cicirelli questioned grown children's filial responsibility by introducing a new phenomenon which he termed "filial anxiety." He found that children in his study experienced anxiety when they anticipated the possibility of providing more help to their aging parents in the future. Cicirelli agreed with previous studies: if elderly parents could no longer remain independent, they expected to receive help from their grown children above all other providers of services. Unfortunately, most adult children in the study not only provided a low level of aid to their parents at the time of the study, but further made it clear that, if their parents' need became greater in the future, they wo uld not feel a commitment to provide any help, or would provide only a little help to the parents (Cicirelli, 1981). This reluctant helping behavior had already been identified in other research. As aged parents became more dependent on their 
offspring, the relationship between the two generations became more problematic (Robinson and Thurnher, 1979).

The aformentioned studies have contributed to the understanding of generational relations. Although frequent contact with offspring does not result in a high level of life satisfaction for elderly parents, parents are not alienated from their offspring, nor are their families isolated from each other. Aged parents are likely to be independent as long as they can. If they become dependent, they expect their children to provide necessary help. While their needs are increasing, the chances for them to get help from their offspring are unfortunately decreasing. Under these circumstances, the relations between parents and their adult children develop difficulties. In short, while isolation of parents from their adult children has been refuted as a social myth, the countermyth of filial responsibility apparently does reflect social reality.

Nevertheless, these previous studies deal with limited aspects of the generational relations. First, there has been much research done concerming mutual interactions between generations. Yet, little is known about the extent to which contact with offspring meets parents' needs. Many generational concerns disregard the question of whether contact with children corresponds with parents' expectations of their children. Second, researchers have blamed parents for the problematic parent-child relationship. However, this 
discordancy may not be due only to parental dependency, illness, or other parental difficulties. It may be argued that adult children likewise should be responsible for maintaining the quality of the relationship. Beside parental difficulties, the unwillingness of grown children to provide the help that their aged parents expect of them should be taken into account as a cause of problems between generations. Therefore, discussions of children's filial behavior in fulfilling parents' expectations must consider the limitations of previous generational studies. Moreover, since earlier research is predominantly concentrated on practical interaction between generations, there is less normative research in this area. The least is known about behavioral and normative comparisons in generational relations. The concept of "filial discrepancies," discussed next, elaborates these comparisons and allows a more accurate characterization of parent-child relationships.

Children's Filial Obligations and Parents' Expectations

Relations between parent and child are viewed as problematic by Bengtson (1979). Families in his study were found to face five separate but related problems dealing with interaction between generations. The first one was role transition, which simply meant "the changing roles and expectations that go along with growing up and growing old" ( $p$. 48). For instance, parents can not expect their children to act the same way they did twenty years ago. Nor can the 
children expect their parents to be what they were twenty years ago. Both parents and children have to make an adjustment to the changing roles and expectations. Bengtson suggested that changing roles, which create different expectations on the part of both parents and offspring, is a basic cause leading to the rest of the problems between the generations: autonomy and dependency; equitable exchange; continuity versus disruption.

Indirectly, Bengtson's suggestions indicate that both parents and offspring are tied to one another through role relationships. This is within the sociological tradition of role theory, which says that every person occupies a set of roles and that a role of one person is linked to another role of another person. Roles are reciprocal, and they define people's obligations and expectations. The expectations of one role occupant are the obligations of the other (Vander Zanden, 1977). Thus, the obligation of the children's role are the expectation of the parents' role. Borrowed from Goffman's definitions of obligation and expectation (1961), offspring's obligations can be regarded as actions of their own that their parents can legitimately demand they perform, while parents' expectations can be considered as legitimate demands that parents can make of their children.

This present study will examine the filial responsibility of adult children based upon parents' expectations. It will also attempt to show the extent to which children 
fulfill their parents' expectations of their behavior.

\section{Filial Discrepancies}

Previous discussions of generational relations indicate that there are differentiations between social normative expectations on the one hand and people's behavioral performance on the other. Kerckhoff (1966) compared normative expectations and behavioral realities in general family relations. His comparative work showed considerable discrepancies between normative definitions and actual behavior in the family studies. Since sociologists acknowledge the discrepancy between ideal and real behavior as a common phenomenon, it can be expected that discrepancies between older parents' expectations of their children and their children's actual behavior towards the parents are not unusual.

If family interaction has been considered as a crucial influence upon the elderly's feelings of satisfaction in late life, why isn't contact with children also an important variable? Weishaus (1979) proposed several explanations for the occurrence of no association or negative association between contact with children and morale in older parents. One of his explanations was that frequent interaction with children may lead parents to have higher expectations and make more demands upon their children. If high expectations are not fulfilled by the children, then parents' morale will be low. This suggests that, if there are discrepancies between parental expectations and children's behavior, these discrepancies 
may have an effect on the older parents' life satisfaction.

Such discrepancies are based on the variations between "filial expectations" of parents and "filial behavior" of children. Therefore, they are appropriately termed "filial discrepancies."

This present study suggests a consideration of discrepancies between parents' filial expectations of their children and the children's filial behavior towards the parents as perceived by parents. It further suggests that filial discrepancies are likely to have influence on the parents' life satisfaction in old age.

In short, a review of pertinent literature shows generally that interactions between the generations are an important focus of discussion. The literature also reveals that there is insufficient research regarding the combination of actual behavior with normative expectations between older parent and their adult children. Therefore, the orientation of this study is to explore the relationship between older American parents and their grown or married children normatively and behaviorally.

The purposes of this study are:

(1) To examine the applicability of disengagement theory to the relationships of aging parents with their adult children; it is hypothesized that the less the engagement of children with their parents, the higher the life satisfaction of the parents. 
(2) To test the significance both of older parents' expectations of their offspring and of the children's behavior towards the parents, as perceived by the parents, on parental life satisfaction.

(3) To study the influence of filial discrepancies (between expected and perceived behavior of children) on the parental psychological well-being.

\section{SUMMARY}

Although there has been considerable debate regarding activity and disengagement theories, both can correctly describe certain aspects of the social-psychological process of aging. The significance of family participation for life satisfaction in old age has been noted. Yet, contact with children has no association or has negative association with life satisfaction of the elderly.

The literature has shown that older parents are not alienated from their offspring, nor do the children feel a strong filial responsibility for their parents. Therefore, despite frequent contact between the generations, if interaction with offspring does not meet older parents' needs, it naturally will not result in a higher level of life satisfaction for elderly parents.

The relationships between elderly parents and their grown children should be studied from the standpoint of reciprocal role relationships: one's expectations are the 
other's obligations.

Since there are many discrepancies between normative definitions and actual behavior found in family studies, it is not surprising that there are also discrepancies between parents' expectations of their children and the children's perceived behavior towards the parents.

This study will establish the concept of "filial discrepancies," which has been developed in the present chapter to supplement the shortcoming and insufficiency of previous research, which has focused only on discussions of interactions between the generations. The main concern of this research is with the influence of filial discrepancies in parent-child relationships on the life satisfaction of the parents. 


\section{CHAPTER III}

\section{METHODOLOGY}

\section{Dependent Variable}

Two aging theories presented earlier have considered psychological well-being as the outcome of successful aging. Activity theory primarily describes the outcome of aging in terms of life satisfaction, while disengagement theory identifies outcome in term of morlae. The terms "life satisfaction" and "morale" are used interchangeably in many instances to reflect a general sense of well-being. However, sociologists usually describe morale in a sense of "integration into a social group." Morale has been referred to as a characteristic of groups or of individuals. Life satisfaction is used to refer to an individual's cognitive assessment of his or her own life condition (George and Bearon, 1980). Since the present study examines elderly parents' life satisfaction in general, not their integration or characteristics, the term "Iife satisfaction" is appropriate to indicate the condition of aging among older parents. Moreover, life satisfaction is persistently used by gerontologists as a criterion for successful aging.

Neugarten, Havighurst, and Tobin (1961) established three useful measures of psychological well-being. Five 
positive components of well-being were developed in their first measures: zest for life or being enthusiastic; resolution and fortitude; congruence between desired and achieved goals; positive image of self; and the maintaining of an optimistic mood and attitudes. They finally adopted the term "life satisfaction" to represent the five components and entitled this measure Life Satisfactıon Rating (ISR).

Since the LSR required a long interview with the respondentent, it was found to be troublesome when used in a large sample. Neugarten and her associates devised two more suitable self-report instruments which would take only a few minutes to administer. They are: Life Satisfaction Index A (ISIA), and Index B (LSIB). Both reflect the five components of life satisfaction. They can be therefore used separately or together. As George and Bearon (1980) comment, the Iife Satisfaction Index is "probably the most widely used instrument for assessing subjective perceptions of well-being among older individuals" (George and Bearon, 1980, p. 47).

The index selected for use in this study is Adams's eighteen-Item Life Satisfaction Index: LSIA-A. It is the revised form of the original twenty-item Index A. There are couple of reasons for using Adams's Index. First, Adams found that two items in the original index did not adequately estimate the satisfaction scale. They are omitted from further use in the index. Second, the correla- 
tion between ISIA and ISIB is found to be less significant than the correlation between ISIA and ISIA-A, which is the most highly correlated pair among several measures of psychological well-being (Lohmann, 1977).

According to George and Bearon, the term "life satisfaction" is defined as "an assessment of the overall conditions of existence as derived from a comparison of one's aspirations to one's actual achievements" (George and Bearon, 1980, p.38).

Operationally, life satisfaction is defined by an individual's averaged scores--mean--on Adams's eighteenItem Index designed to measure whether he or she is satisfied with his or her life generally, in past, present, and future prospects.

\section{Independent Variables}

There is agreement among some family sociologists regarding the relations between aged parents and their adult children. It has been found that interaction between the two generations is more frequent than the social myth of alienation had indicated. However, research has shown that frequent contact with offspring does not result in a higher level of life satisfaction for elderly parents. The previous chapter raised the question of whether the interaction with offspring would meet parents' personal needs. It was argued that, besides interaction, expectations and role responsibility should also be taken into consideration 
in parent-child relationships.

The independent variable in this study is the parentchild relationships in old age--PCR. Although the literature lacks a suitable definition for PCR, from previous studies one can infer the definition as comprising the emotional, expectational, and behavioral connection between older parents and their adult or married children. As the orientation of this research was to explore the generational relation from a comparison of normative and behavioral components, the definition of PCR was developed as: an evaluation of the overall conditions of relations as derived from a comparison of parents' filial expectations of their children with the children's filial behaviors toward the parents.

The evaluation of PCR is determined by three variables: filial expectations, filial behavior, and filial discrepancies.

According to Seelbach and Sauer (1977), filial expectation (FE) can be defined as the level of expectations which parents have regarding the duties or obligations of their offspring to fulfill the parents needs. Operationally, it is defined by parents' scores on a thirteen-statement index designed to assess their expectations for living arrangement, care responsibility, financial aid, affectionate support, and contact by their offspring. Single statement scores ranged from strong disagreement (I) to strong agreement (5). 
Filial behavior (FB) refers to the actions that children perform as viewed by their parents in fulfilling the parents filial expectations. This term is defined operationally by parents scores on the questions about behavior which are similar to those questions on the filial expectations' thirteen-statement index. The questions are designed to measure parents' perception of the level of their children's actual behavior in fulfilling parental expectations.

Filial discrepancies (FD) are the result of the comparison of parents' filial expectations with their children's filial behavior. Discrepancies are the differences between the expected and perceived filial behaviors of children by their parents. Discrepancy scores between behavior and expectations should be zero or slightly positive, if the level of children's behavior is equal to or higher than the level of parents' expectations. The scores will be negative if the perceived behavior falls short of the level of expectations.

\section{Hypotheses}

From a review of pertinent literature and the discussions in the previous chapter, one basic hypothesis has been formulated for this study: that life satisfaction of elderly parents is strongly related to parent-child relationships in old age--PCR.

The PCR consists of two components: expectations and behavior. Each one has it's own relationship with life 
satisfaction. According to Seelbach and Sauer's findings (1977): level of parents filial expectations was significantly and inversely associated with level of parental morale. Therefore, the present study hypothesized that there is an inverse relationship between expectations and life satisfaction. Earlier research suggested that contact with offspring had no relationship or had only a negative relationship with parental life satisfaction. In this study, however, the contact children have with their parents is viewed as a significant factor in the interaction between the two generations. Thus, contrary to the earlier research, it was hypothesized that children's filial behavior towards parents has a positive relationship with parental life satisfaction.

PCR also involves a comparison of parents' filial expectations to their offspring's filial behavior. The results of the comparison--filial discrepancies--are believed to be associated with the parents' life satisfaction. If the level of children's filial behavior toward their parents is higher than the level of their parents filial expectations of them, it will result in a higher level of the parents life satisfaction. Otherwise, if the level of filial expectations is higher than the level of filial behavior, the parent will have a lower level of life satisfaction. Thus, the positive scores of discrepancies are associated with a higher level of life satisfaction, the 
negative scores with a lower level of life satisfaction. In other words, if an elderly parent is aging successfully, his filial expectations would be on the average lower than his children's filial performance in carrying out the expectations. The hypotheses of this study are:

1. Life satisfaction of elderly parents has a negative correlation with their filial expectations of their children, but their life satisfaction has a positive correlation with their children's filial behavior;

2. There is a correlation between life satisfaction of elderly parents and filial discrepancies: the positive scores of discrepancies are correlated with higher level of life satisfaction; the negative scores are correlated with lower level of life satisfaction.

Instrument

A questionnaire was constructed to test these hypotheses and to measure the relationships between dependent and independent variables. An introductory statement in the form of a letter was sent along with the self-administered and mailed-out questionnaire to help the respondents cooperating in the survey (Appendix A). The questionnaire itself has four sections. The first concerns the respondent's basic backgrounds. In reviewing the literature, several correlates of life satisfaction have been found to be important for the aged. Besides participation in family activities, four other areas also have an effect on the life satisfaction of elderly people. They are health, socioeconomic status (including occupation, educational level, and income), informal social activities with friends, and for- 
mally organized social activities (Adams, 1971; Bell, 1967; Bultena and Oyler, 1971; Conner et al., 1979; Edwards and Klemmack, 1973; Ellison, 1969; Graney, 1975; Larson, 1979; Lemon et al., 1972; Maddox, 1962; Markides and Martin, 1979; Medley, 1976; Palmore and Luikart, 1972; Palmore, 1979; Spreitzer and Snyder, 1974).

Socioeconomic status was expected to be less important in this study due to the fact that members of senior centers (the source of the sample) are primarily of the middle class (Tissue, 1971). Still, respondents' occupations and their judgements of their own financial situation were regarded as important variables. Therefore, questions in the first section include marital status, age, gender, number of children, occupation, living arrangement, activities with informal organizations (i.e. church, senior center, clubs), activities with relatives and friends, financial situation, and health condition (See Appendix A).

The second part of the questionnaire is Adams's eighteen-item Life Satisfaction Index. This index measured the dependent variable. The next part is the thirteen-statement Filial Expectation Index (FEI), which measured the level of normative expectations that parents have of their children. The index is based on Seelbach and Sauer's sixitem index, which has questions concerning living arrangement with offspring, children's care responsibility, financial help, visits, correspondence, and feelings of obligation toward their parents (Seelbach and Sauer, 1977). Chil- 
dren's affectionate support, conformity with parents' opinions, respectfulness to parents suggestions, and purpose for having offspring are also believed to be as important as Seelbach and Sauer's six questions. Thus, there are thirteen statements all together that measure parents' expectations (See Appendix A).

Respondents answer on the LSIA-A and FEI by choosing one of five altematives from a Likert-type scale. The choices are "strongly agree," "agree," "not sure," "disagree," and "strongly disagree." In FEI, the scores are given from five points to one point, respectively. In LSIAA, single item scores also ranged from five to one. The scores were based on a standard formulated by Neugarten and her associates (1961). In the original index LSIA, there were three alternatives: "disagree," "agree," and a question mark "?." One point was given to each answer which agreed with a positive statement or disagreed with a negative statement. Thus, respondents' scores were the total points from the measured answers. Neugarten and her associates were not concerned with blank or inapplicable answers. In this study, five points were given to each answer which strongly agrees with a positive statement or strongly disagrees with a negative statement, four points to an agreement with a positive statement or a disagreement with a negative statement, three points to an uncertain answer, two points to an agreement with a negative statement or to a disagreement with a positive statement, and one 
point to a strong agreement with a negative statement or a strong disagreement with a positive statement. The expanded scoring format was used in order to make socre ranges comparable across different scales.

The final section of the questionnaire concerns children's filial behavior towards their parents. Because the questionnaire was designed for parents, the "actual filial behavior" of children was evaluated as perceived by their parents. Questions in this part are similar to those on the FEI, plus parents' general evaluation of their children's behavior. Thus, fourteen items are in this Filial Behavior Index (FBI) (See Appendix A).

The fourteen items had various choices: three items had five choices (scores ranged from five to one), the same as in FEI; eight items had seven alternatives (scores measured from seven points to one point); two items had "yes" and "no" choices (scores two or one point); one question regarding children's living areas had multiple choice and multiple scores.

For analytical purposes, the scores in each index-LSIA-A, FEI, and FBI--were averaged by the number of questions answered, because such a mean would better represent the true value of a variable (Blalock, 1960). Thus, the mean of LS was used to indicate the overall condition of each respondent's life satisfaction. Used in this manner, the mean also takes into account the blank or inapplicable 
answers by respondents. Similarly, the mean can index each parent's expectational level and his or her children's behavioral level. Since various scales were used in the behavioral index, scores of FB were standarized to the same levels as those of $\mathrm{FE}$, then added and averaged, in order to compare and to determine the level of filial discrepancies. The scores of filial discrepancies in each case were computed from the mean of $\mathrm{FB}$ minus the mean of $\mathrm{FE}$.

\section{Data Gathering Procedure}

The data for this study were collected from the city of Portland, Oregon. The sampling procedure entailed collecting samples from three senior citizen centers: Friendly House Senior Center, in northwest Portland; Hollywood Senior Center, in the northeast; and the Neighborhood Senior Center, in the southwest. There were two reasons for selecting the sample from senior citizen centers. First, Atchley (1980) indicated that excepting institutionalized and immobile elderly, members of senior centers do not seem to be very different from other older people. Thus, people from senior centers can represent the average American elderly. The second reason was that the staff of these centers were enthusiastic to help conduct the survey.

The subject of this study was the elderly parents. Unfortunately, the staff did not know how many members on their mailing lists were parents. Moreover, it was contary to the rules of the organizations to release members' names 
and addresses from these centers. As a result, according to the number of their members, the staff of these centers decided to select every khth member from their mailing lists. Then, they sent out the questionnaires directly to potential respondents.

Questionnaires were mailed out through senior centers on different dates. Starting on October 13, 1982, Friendly House distributed questionnaires directly to sixty individuals, every 15th member on their mailing list. Hollywood Center mailed out seventy copies on October 19 by selecting every 20 th member from its list as a recipient. Neighborhood Center chose every 15th member and mailed out sixty copies on october 26 . The first returned copy was dated October 15 and the last one was November 22. In total; sixty-nine questiunnaires were received from a total one hundred and ninety distributed. The response rate was thirty-six percent.

of the total sixty-nine returned copies, fifty-two were complete and usable. Of the fifteen unusable copies, four were returned blank, nine were complete in three sections but blank in the last one due to the lack of children, two were partially complete. There were two complete copies that were not used in this study, because in one case the only child had died, and in the other case the recipient was not old enough to be qualified as "old parent," defined to be at least sixty years old. It was originally intended 
to collect data from parents sixty-five years old or older. Since the sample size was quite small, parents' age was lowered to the age of sixty.

\section{The Sample}

The studied group consisted of eleven males and fortyone females. This composition reflected not only the greater number and percentage of females in the older population but also the greater propensity of women to participate in survey studies (Wood et al., 1969). Age of the respondents ranged from sixty to eighty-six, with a mean age of seventytwo. Of the fifty respondents, twenty-one were widowed (among them, eighteen were female, three were males), twenty were married (thirteen females, seven males), eight were divorced and one woman was separated. The average participant had two children, with a range of one to six children. From a total of one hundred and thirty-two children of all participants, one hundred and six had married and sixteen who had reached the age of twenty-one were single. The parents did not specify the marital status or the age of the ten remaining children.

Forty-one people in the sample were retired, seven were not. Occupations were rated, based on the code book of National Data: A Program for the Social Sciences, 1975. The range of ratings was from the lowest 15--newsboys--to the highest 82--physicians. In this study, the average occupation rating was 42 . The highest rating job was 67-- 
engineer. The lowest was laborer--17. Five were housewives. Eleven did not answer. One man's job could not be found in the code book. Except those who were still in the labor market, thirty-three retirees were not looking for any job, and nine were working part-time.

of forty-nine respondents, twenty-five lived by themselves, twelve lived with spouse, two lived with spouse and children, five with their children only. The rest of them lived with relatives or friends.

Most of the respondents appeared in good health: thirty-seven felt themselves to be either in good or in very good health, twenty-one reported their health as fair, and only three claimed having poor or very poor health. In regarding to financial situation, only three reported themselves as poor, twenty-two as fair, eighteen as good, and eight as very good.

The respondents appeared to have their most frequent contact with friends, religious groups, and relatives. They seemed to be less interested in the activities held by the senior centers and by other organizations or clubs. Although the samples were obtained from the senior centers' mailing lists, participation in these centers' activities was the lowest among the several kinds of contact.

\section{Data Analyses}

Since the object of this study was to explore the older parent-adult children relationships normatively and 
behaviorally, qualitative and quantitative methods were involved in analyzing the data.

First, Pearson correlatıon coefficients were computed to measure the strength of the relationship between variables in the indexes: LSIA-A, FEI, and FBI. Quantitative analysis could indicate how consistently the index of LSIA-A measured the dependent variable of life satisfaction, and how consistently the indexes of FEI and FBI measured the independent variables of filial expectations and filial behavior.

Second, data from the study sample were tabulated to observe the frequency distribution of all variables. The tabulations employed illustrated the respondents' backgrounds, their feelings about their lives, their expectations of their adult children, and their children's behavior towards them. The third step of analysis was cross-tabulation to observe the joint distribution of measures of respondents' backgrounds in order to learn the characteristics of the respondents.

The next series of analyses was done to test the hypotheses--that the life satisfaction of the elderly parent is negatively correlated with their filial expectations; the life satisfaction of the parent is positively correlated with their children's filial behavior; the positive scores of discrepancies between filial expectations and filial behaviors are correlated with higher levels of life satisfaction, and the negative scores of discrepancies are cor- 
related with lower levels of life satisfaction. Pearsonion correlation coefficients were computed to measure the relationships between the dependent and independent variables.

In the final phase, a partial correlation analysis was conducted. This was done for two reasons. First, if significant associations were found between the dependent variable and each independent variable, partial correlation was used to examine whether those associations were spurious. Second, if the associations between the variables were found to be spurious, partial correlation could find the additional variables affecting the associations. 


\section{CHAPTER IV}

\section{RESULTS}

The results of this study are presented in three major sections. The first describes the characteristics of the instruments--ISIA-A, FEI, and FBI. The next section is devoted to both quantitative and qualitative descriptions of the respondents' backgrounds, their expectations of their adult children, and their perceptions of their children's behavior in fulfilling the expectations. These are followed by the last section which is a quantitative analysis of the hypotheses.

\section{CHARACTERISTICS OF THE INSTRUMENTS}

To measure the strength of the relationship between the items in each index, Pearson product-moment correlation coefficients were computed. In each index, if the relationships among the items were statistically significant and positive, the items were considered to measure one common variable.

* It was recognized that, since the group of respondents in this study was not a true random sample, the use of significance tests is not technically justified. The significance levels are shown, nevertheless, for purpose of comparison. 


\section{Life Satisfaction Index--LSIA-A}

The general life satisfaction of the older respondents was measured by Adams's eighteen-statement Life Satisfaction Index, consisting of eleven positive and seven negative statements.

In reviewing the relationship among the eighteen statements in LSIA-A, seventeen had intercorrelations with at least three other statements above $r=.30(p<.05)$. Four paired statements were correlated above $r=.50$. Only one statement, "In spite of what people say, the lot of the aterage man is getting worse, not better," correlated with the rest of the statements below $r=.29$. Although this statement had low correlations with the others, it was still maintained in the index to determine the level of life satisfaction. There were several reasons for not removing it. First, having examined the reliability of all the eighteen statements, Adams affirmed that these statements appeared to perform quite evenly in contributing to the total life satisfaction scores (Adams, 1969). In addition, a national survey conducted by Louis Harris in 1974 adopted Adams's index for measuring the level of life satisfaction of people aged eighteen and older (Louis Harris and Associates, 1975). Third, Wood, Whylie, and Sheafor's thirteen-statement life Satisfaction Index Z, used by several studies, also utilized that statement (Bultena and Oyler, 1971; Conner et al., 1979; Markides and Martin, 1978; Wood et al., 1966). To make the 
present study comparable to earlier studies, all items were retained in the scale. The intercorrelations of these items are reported in Appendix $B$.

\section{Filial Expectation Index--FEI}

The Filial Expectation Index, which measured parents' expectations of their grown children, included thirteen positive statements. Of these, eleven were correlated with at least five other statements above $r=.30(p<.05)$; two statements were correlated with only one other statement above $r=30$. The two statements with low correlations were those regarding living arrangements with children and regarding the purpose for having children. They were not retained in the index to determine the level of filial expectation, because of their low relationships with the rest of statements in the index.

Several items had strong interrelationships. If children lived far away, their parents expected them to make longdistance phone calls as well as to write letters to them $(r=.75)$. Two other items, "Children should comfort their parent when they are depressed," and "Children should take care of their parents in whatever way necessary when they are sick," were strongly correlated $(r=64)$. Therefore, when parents expected their children to take care of them "physically," they also expected their children to take care of them "emotionally."

Relationships among the items in FEI were generally 
stronger than the relationships among the statements in LSIAA (Appendix C).

\section{Filial Behavior Index--FBI}

The Filial Behavior Index had fourteen questions which corresponded with the statements in the Filial Expectation Index. There seemed to be stronger relationships among the items of the FBI than of the FEI. In particular, there were higher correlations between questions conceming the last time the respondents received financial help, telephone calls, letters, or visits from their children, and the questions about the frequencies of those types of contacts with the children. If children had come to visit their parents during the day or the week prior to the survey, they were considered to visit the parents "more than once a week" or "weekly." The correlation was $r=.85$ between the items "the last time of children's visits" and "frequencies of visits." There were associations between the distance the children lived from their parents and the time of their last visit, phone calls, and the frequency of their visits or phone calls. The closer the children lived to their parents, the more frequent the contact by the children with their older parents. The categories: "children lived in the same neighborhood" and "frequencies of visit" were correlated at $r=.56$, whereas, "the last time of children's visits" and "children living in another state" were negatively related, $r=-.53$ (Appendix D). 
Refinement of the Scales

The examination of the relationships among the items of the index indicated that LSIA-A, FEI, and FBI do measure three major variables of this study: life satisfaction, filial expectations, and filial behavior, respectively. It was decided to use LSIA-A without alternations, as it has been used as an instrument for measuring the level of life satisfaction in previous studies. However, FEI and FBI were revised to improve the reliability of the measurement. Two reasons for the revision in FEI and in FBI are presented in the following paragraph.

First, there were some difficulties in measuring the distance the children lived from their parents. Most respondent reported different offspring living in several different areas rather than just in one area. Consequently, questions concerning living arrangements of the offspring were removed from FBI. Second, due to lack of variance in response, three statements were removed from the FEI: two statements relating to the living arrangement and one statement regarding the purpose of having children. Responses to statements like, "Children should live with their parents" and "One of the important reasons for having children is that parents will have their children to take care of them when they are old" were rather uniformly, "Strongly disagree" and "Disagree." As mentioned earlier, those two statements had lower correlations with the rest of statements in the FEI. Therefore, 
these questions were eliminated from further use in the analysis. Both the FEI and the FBI as utilized had corresponding questions, making possible a comparison between indexes to determine the scales of filial discrepancies: the difference between parents' expectations and children's behavior.

CHARACTERISTICS OF THE RESPONDENTS

This study group consisted primarily of widowed and married people. A widowed person was more likely to live alone than were married, divorced, or separated persons. Sixteen out of twenty-five respondents who lived alone were widowed. Of nineteen married people, fourteen lived with spouse or with spouse and children (Table I).

\section{TABLE I}

IIVING ARRANGEMENTS BY MARITAL STATUS

\begin{tabular}{|l|c|c|c|c|c|}
\hline $\begin{array}{r}\text { marital } \\
\text { living status } \\
\text { arrangement }\end{array}$ & widowed & divorced & separated & married & total \\
\hline living alone & 15 & 5 & 0 & 5 & 25 \\
\hline with friends & 0 & 1 & 1 & 0 & 2 \\
\hline with relatives & 0 & 1 & 0 & 0 & 1 \\
\hline with offspring & 4 & 1 & 0 & 0 & 5 \\
\hline with spouse & 0 & 0 & 0 & 12 & 12 \\
\hline $\begin{array}{l}\text { with spouse \& } \\
\text { offspring }\end{array}$ & 0 & 0 & 0 & 2 & 2 \\
\hline total & 19 & 8 & 1 & 19 & 47 \\
\hline
\end{tabular}


Among the social activities of the elderly, it seemed that those who were active with friends were more likely to participate in other social activities. Contact with friends was the variable most correlated with other variables of activities (Table II).

\section{TABLE II}

CORRELATIONS AMONG ACTIVITY VARIABLES

\begin{tabular}{|l|c|c|c|c|c|}
\hline & ACTRG & ACTSC & ACTCO & ACTRT & ACTFR \\
\hline ACTRG & & $.29^{*}$ & .16 & .20 & $.15^{*}$ \\
\hline ACTSC & & & .15 & .18 & $.35^{*}$ \\
\hline ACTCO & & & & .25 & $.43^{*}$ \\
\hline ACTRT & & & & $.40^{*}$ \\
\hline
\end{tabular}

$* \mathrm{p}<.05$

EXPLANATIONS OF VARIABLES

ACTRG: activity with religious groups
ACTSC: activity in senior centers
ACTCO: activity in clubs or organizations
ACTRT: activity with relatives
ACTFR: activity with friends

According to the mean in each activity area, the respondents showed the highest level of participation in activities with friends, the second highest with relatives, third, participation in religious groups, fourth, participation was in organizations and clubs. Respondents had generally a moderate level of social activity (Table III).

Neugarten divided the elderly into two age groups: the young-old and the old-old, the age of seventy-five being the division line (Neugarten, 1975). Unlike Neugarten's division, the present study group was divided into three age 
TABLE III

LEVELS OF SOCIAL ACTIVITY

\begin{tabular}{|c|c|c|}
\hline SCALES & FREQUENCIES & $\bar{N}$ \\
\hline $0.0-0.9$ & 1.9 & 1 \\
\hline $1.0-1.4$ & 1.9 & 1 \\
\hline $1.5-1.9$ & -9 & 0 \\
\hline $2.0-2.4$ & 15.4 & 8 \\
\hline $2.5-2.9$ & 9.6 & 5 \\
\hline $3.0-3.4$ & 21.2 & 11 \\
\hline $3.5-3.9$ & 13.5 & 7 \\
\hline $4.0-4.4$ & 23.1 & 12 \\
\hline $4.5-4.9$ & 5.8 & 3 \\
\hline $5.0-5.0$ & 7.7 & 4 \\
\hline mean: 3.4 \\
minimum score: 0.7 \\
maximum score: 5.0
\end{tabular}

groups: the "young-old," between sixty and sixty-four; the "middle-old," from sixty-five to seventy-five; and the "oldold" seventy-six and older. There were seven people in the first group, twenty-eight in the second, and seventeen in the third.

Examination of the association between age and the level of activity showed that those in the middle-old age group had a higher level of participation in activities than those in the young-old and in the old-old groups (Table IV).

\section{TABLE IV}

RELATIONSHIP BETWEEN AGE AND THE LEVEL OF ACTIVITY*

\begin{tabular}{|c|c|c|c|c|c|}
\hline act age & $60-64$ & $65-75$ & 76 & Total & \multirow{5}{*}{$\begin{array}{l}\text { The level of } \\
\text { activity was } \\
\text { divided at } 3 \cdot 5 \\
\text { high act: } 3 \cdot 6-5.0 \\
\text { low act: } 0.7-3 \cdot 5\end{array}$} \\
\hline high act & 3 & 16 & 7 & 26 & \\
\hline low act & 4 & 12 & 10 & 26 & \\
\hline Total & 7 & 28 & 17 & 52 & \\
\hline * Gamma & .12 & & & & \\
\hline
\end{tabular}


In some activity areas, older age had an inverse relationship with participation: in religious groups, in the activities held by organization or clubs, and in activities with relatives. Gammas were $-.20,-.30$, and -.32 , respectively. However, the relationship was not statistically significant, suggesting that as age increases many people still keep active in some social activities.

Age was not related to other areas. For example, oldold respondents experienced variations of their financial and health condition the same as the young-old or the middle-old groups did.

Occupational ratings indicated that the study group was basically middle-class. Cross-tabulations showed that occupational position was not associated with most variables. For instance, it was not related to the number of offspring or reports of financial and health conditions. Even though occupational position had an association with participation in senior centers (gamma $=.40)$, the other social activities had no relationship with occupational position.

Respondents were asked to compare themselves with others of their age and then to rate their finance and health. Most reported their finances and especially their health were in a good state. However, those two indicators of respondents' backgrounds appeared to have no relationship with any of their social activities. 


\section{Iife Satisfaction}

On the majority of statements tested, elderly participants indicated high life satisfaction. Nine out of ten respondents felt, "Compared to other people my age, I make a good appearance." Eighty-five percent of the respondents did not think that most of the things they did were boring and monotonous. Eighty-three percent of those sixty and over agreed with the statement, "As I look back on my life, I am fairly well satisfied." When compared to other people, three out of four did not feel that they "get down" too often. The same proportion also disagreed with the statement, "This is the dreariest time of my life." Seventy-one percent still expected some interesting and pleasant things to happen to them in the future, and also had made plans for things they would be doing in the near future. They further felt that they had gotten pretty much what they expected out of life. As they become older, seventy percent of the respondents felt that things would be better than they had thought they would be. Nearly one-fourth of the respondents made "not sure" responses to two statements, one concerned with getting more breaks in life than others and the other with things seeming better in old age than they expected. The remaining responses are given in Table $\mathrm{V}$, which presents positive statements separately from the negative statements. 
TABLE V

RESPONSES TO LIFE SATISFACTION INDEX

\begin{tabular}{|c|c|c|c|c|c|}
\hline Statements & & & onse & & \\
\hline Positive Statements: & $\begin{array}{l}\text { strongly } \\
\text { agree }\end{array}$ & agree & $\begin{array}{l}\text { not } \\
\text { sure }\end{array}$ & $\begin{array}{l}\text { d18- } \\
\text { agree }\end{array}$ & $\begin{array}{l}\text { strongly } \\
\text { disagree }\end{array}$ \\
\hline $\begin{array}{l}\text { Compared to other people my age, I make a good appearance } \\
\text { As I look back on my life, I am fairly well satisfied } \\
\text { I expect some interesting and pleasant things to happen } \\
\text { to me in the future } \\
\text { I've made plans for things I'Il be doing a month or a } \\
\text { year from now } \\
\text { The things I do are as interesting to me as they ever were } \\
\text { I've gotten pretty much what I expected out of life } \\
\text { As I grow older, things seem better than I thought they } \\
\text { would be } \\
\text { I am just as happy as when I was younger } \\
\text { I've gotten more of the breaks in life than most of the } \\
\text { people I know } \\
\text { I would not change my past life even if I could } \\
\text { These are the begt years of my life }\end{array}$ & $\begin{array}{r}15.4 \\
(8) \\
17.3 \\
(9) \\
7.7 \\
(4) \\
5.8 \\
(3) \\
13.5 \\
(7)\end{array}$ & $\begin{array}{l}50.0 \\
(26) \\
48.1 \\
(25) \\
65.4 \\
(34)\end{array}$ & $\begin{array}{r}23.1 \\
(12) \\
13.5 \\
(7) \\
21.2 \\
(11)\end{array}$ & $\begin{array}{l}21.2 \\
(11) \\
30.8 \\
(16) \\
28.8 \\
(15)\end{array}$ & $\begin{array}{l}1.9 \\
(1) \\
5.8 \\
(3) \\
- \\
5.8 \\
(3) \\
7.7 \\
(4)\end{array}$ \\
\hline $\begin{array}{l}\text { My life could be happier than it is now } \\
\text { In spite of what people say, the lot of the average man } \\
\text { is getting worse, not better } \\
\text { Wher. I think back over life, I didn't get most of the } \\
\text { important things I wanted } \\
\text { I feel old and somewhat tired } \\
\text { This is the dreariest time of my life } \\
\text { Compared to other people, I get down in the dumps too } \\
\text { often } \\
\text { Most of the things I do are boring and monotonous }\end{array}$ & $\begin{array}{l}1.9 \\
(1) \\
1.9 \\
(1) \\
5.8 \\
(3) \\
1.9\end{array}$ & $\begin{array}{l}30.8 \\
(16) \\
23.1 \\
(12) \\
20.5 \\
(13) \\
11.5 \\
(6) \\
5.8 \\
(3) \\
3.8 \\
(2)\end{array}$ & $\begin{array}{r}7.7 \\
(4) \\
13.5 \\
(7) \\
11.5 \\
(6) \\
5.8 \\
(3) \\
13.5 \\
(7) \\
5.8 \\
(3)\end{array}$ & $\begin{array}{l}42.3 \\
(22) \\
44.2 \\
(23) \\
34.6 \\
(18) \\
46.2 \\
(24) \\
38.5 \\
(20) \\
42.3 \\
(22)\end{array}$ & $\begin{array}{r}11.5 \\
(6) \\
15.4 \\
(8) \\
21.2 \\
(11) \\
28.8 \\
(15) \\
36.5 \\
(19) \\
42.3 \\
(22)\end{array}$ \\
\hline
\end{tabular}

* Percentege

* Number of Responses 
Filial Expectations

What do elderly parents in this study expect of their grown children? As mentioned previously, four-fifths of the fifty-two parents strongly disagreed or disagreed with the statements, "Children should live wi th their parents" and "One of the important reasons for having children is that parents will have their children to take care of them when they are old." On the other hand, parents appeared to have greater concern about affectionate support, respect, and care responsibility from their offspring. They also expected frequent contact from their children through telephone calls and correspondence. More than half of them expected their children to provide financial aid. The parents seemed to be less in favor of close living arrangements with their offspring. Even if their offspring lived nearby, most of them did not like weekly visits from the offspring (Table VI). These findings show both consistencies and inconsistencies with previous studies. Schorr (1960), Streib (1958; 1965), and Sussman (1953; 1965) indicated that instead of money, affection was what elderly parents valued most from their grown children. Watson and Kivett (1976) also found that parents had low expectations of monetary assistance from their offspring. In this present study, affectionate support was the behavior most expected by parents from their children However, more than half of the parents in this study expected financial assistance from their next generation. 
TLBLE $n$

RESPOISES TO FILIAL EXPECTATION IIDEKX

\begin{tabular}{|c|c|c|c|c|c|}
\hline \multirow{3}{*}{\begin{tabular}{|l} 
Statements \\
$\begin{array}{l}\text { Children should coufort their perents, when they are } \\
\text { depressed }\end{array}$
\end{tabular}} & \multicolumn{5}{|c|}{ Responses } \\
\hline & $\begin{array}{c}\text { strongl } \\
\text { egree }\end{array}$ & y & $\begin{array}{l}\text { not } \\
\text { sure }\end{array}$ & $\begin{array}{l}\text { dis- } \\
\text { sgree }\end{array}$ & $\begin{array}{l}\text { strongly } \\
\text { disagree }\end{array}$ \\
\hline & $1.9 * *$ & $\begin{array}{l}76.9 \\
(40)\end{array}$ & $\begin{array}{l}9.6 \\
(5)\end{array}$ & $\begin{array}{l}7.7 \\
(4)\end{array}$ & $\begin{array}{l}3.8 \\
(2)\end{array}$ \\
\hline 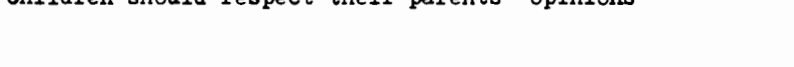 & $\begin{array}{l}7.7 \\
(4)\end{array}$ & $\begin{array}{l}63.5 \\
(33)\end{array}$ & $\begin{array}{r}15.4 \\
(8)\end{array}$ & $\begin{array}{l}9.6 \\
(5)\end{array}$ & $\begin{array}{l}3.8 \\
(2)\end{array}$ \\
\hline $\begin{array}{l}\text { Children should take care of their parents in whatever } \\
\text { way necessary, when they are sick }\end{array}$ & $\begin{array}{l}7.7 \\
(4)\end{array}$ & $\begin{array}{l}57.7 \\
(30)\end{array}$ & $\begin{array}{l}19.2 \\
(10)\end{array}$ & $\begin{array}{l}9.6 \\
(5)\end{array}$ & $\begin{array}{l}3.8 \\
(2)\end{array}$ \\
\hline $\begin{array}{l}\text { Children living at a distance should call their parents } \\
\text { at least once a month }\end{array}$ & $\begin{array}{r}11.5 \\
(6)\end{array}$ & $\begin{array}{l}51.9 \\
(27)\end{array}$ & $\begin{array}{r}15.4 \\
(8)\end{array}$ & $\begin{array}{r}15.4 \\
(8)\end{array}$ & $\begin{array}{l}5.8 \\
(3)\end{array}$ \\
\hline $\begin{array}{l}\text { If children live nearby, they should call their parents } \\
\text { at least once a week }\end{array}$ & $\begin{array}{l}7.7 \\
(4)\end{array}$ & $\begin{array}{l}63.5 \\
(33)\end{array}$ & 1.9 & $\begin{array}{l}21.2 \\
(11)\end{array}$ & $\begin{array}{l}5.8 \\
(3)\end{array}$ \\
\hline $\begin{array}{l}\text { Children living at a distance should write to their } \\
\text { parents at least once a month }\end{array}$ & $\begin{array}{l}9.6 \\
(5)\end{array}$ & $\begin{array}{l}48.1 \\
(25)\end{array}$ & $\begin{array}{r}17.3 \\
(9)\end{array}$ & $\begin{array}{r}17.3 \\
(9)\end{array}$ & $\begin{array}{l}5.8 \\
(3)\end{array}$ \\
\hline $\begin{array}{l}\text { Children should be wllling to give their parents financial } \\
\text { help }\end{array}$ & (1) & $\begin{array}{l}51.9 \\
(27)\end{array}$ & $\begin{array}{r}15.4 \\
(8)\end{array}$ & $\begin{array}{l}26.9 \\
(14)\end{array}$ & $\begin{array}{l}3.8 \\
(2)\end{array}$ \\
\hline Children should feel responsible for their parents & $\begin{array}{l}3.8 \\
(2)\end{array}$ & $\begin{array}{l}38.5 \\
(20)\end{array}$ & $\begin{array}{r}15.4 \\
(8)\end{array}$ & $\begin{array}{l}30.8 \\
(16)\end{array}$ & $\begin{array}{r}11.5 \\
(6)\end{array}$ \\
\hline $\begin{array}{l}\text { Children should be willing to accept their parents } \\
\text { suggestions }\end{array}$ & - & $\begin{array}{l}36.5 \\
(19)\end{array}$ & $\begin{array}{l}19.2 \\
(10)\end{array}$ & $\begin{array}{l}38.5 \\
(20)\end{array}$ & $\begin{array}{l}5.8 \\
(3)\end{array}$ \\
\hline $\begin{array}{l}\text { Children who do not live with their parents should live } \\
\text { close to them }\end{array}$ & $\begin{array}{l}3.8 \\
(2)\end{array}$ & $\begin{array}{l}30.8 \\
(16)\end{array}$ & $\begin{array}{r}17.3 \\
(9)\end{array}$ & $\begin{array}{l}34.6 \\
(18)\end{array}$ & $\begin{array}{r}11.5 \\
(6)\end{array}$ \\
\hline $\begin{array}{l}\text { If children live nearby, they should visit their parents } \\
\text { at least once a week }\end{array}$ & $\begin{array}{l}3.8 \\
(2)\end{array}$ & $\begin{array}{l}25.0 \\
(13)\end{array}$ & $\begin{array}{l}19.2 \\
(10)\end{array}$ & $\begin{array}{l}44.2 \\
(23)\end{array}$ & $\begin{array}{l}5.8 \\
(3)\end{array}$ \\
\hline Children should live with thelr parents & $\begin{array}{l}5.8 \\
(3)\end{array}$ & $\begin{array}{l}7.7 \\
(4)\end{array}$ & (i) & $\begin{array}{l}53.8 \\
(28)\end{array}$ & $\begin{array}{l}30.8 \\
(16)\end{array}$ \\
\hline when they are old & $\begin{array}{l}1.9 \\
\text { (1) }\end{array}$ & $\begin{array}{l}3.8 \\
(2)\end{array}$ & $\begin{array}{r}11.5 \\
(6)\end{array}$ & $\begin{array}{l}44.2 \\
(23)\end{array}$ & $\begin{array}{l}36.5 \\
(19)\end{array}$ \\
\hline
\end{tabular}

* Percentage

* Number of Responses 
The majority of parents in the earlier research preferred to live near by but not with their offspring (Brody, 1970; Schorr, 1960; Shanas, 1962; 1979a). The parents in the present sample were similarly in favor of separate living arrangement. Moreover, they seemed to have a slight preference for not living nearby their offspring.

Maddox (1973) claimed that parents' expectation of frequent contact from their offspring was overestimated by the general public. Although the group in this study showed relatively high expectations for frequent phone calls and letters from the children, they showed a lower level of expectation for frequent visits.

\section{Filial Behavior}

Generally, children of the respondents did not live far away from their parents. Sixty-five percent of the parents had at least one of their children living within the Portland area. The data were consistent with Shanas's (1979a) findings which indicated that the majority of older people lived close to at least one of their children. Of the one hundred and twenty-seven children whose residences were specified by the parents, fifty-nine lived within the Portland area, seventeen resided in some other part of Oregon, forty-seven lived in another state, and four lived in a foreign country (Table VII).

Research has found that, when in need of assistance and particularly in times of crisis, parents primarily turn 
TABLE VII (A)

THE DISTRIBUTION OF CHILDREN'S LIVING ARRANGENENTS

\begin{tabular}{|c|c|c|c|c|c|c|}
\hline $\begin{array}{l}\text { LV WITH } \\
\text { PARENTS }\end{array}$ & $\begin{array}{l}\text { LV IN } \\
\text { SAME } \\
\text { NGBOR }\end{array}$ & $\begin{array}{l}\text { LV IN } \\
\text { PORT- } \\
\text { LAND }\end{array}$ & $\begin{array}{l}\text { LV IN } \\
\text { OREGON } \\
\text { STATE }\end{array}$ & $\begin{array}{l}\text { LV IN } \\
\text { OTHER } \\
\text { STATE }\end{array}$ & $\begin{array}{c}\text { LV IN } \\
\text { OTHER } \\
\text { COUNTRY }\end{array}$ & $\begin{array}{c}\text { NUMBER } \\
\text { OF } \\
\text { PARENTS }\end{array}$ \\
\hline $\mathrm{X}^{*}$ & $\mathrm{X}$ & & $\mathrm{X}$ & $\mathrm{X}$ & & 1 \\
\hline $\bar{X}$ & $\bar{X}$ & & & & & 1 \\
\hline $\mathrm{X}$ & & $\bar{X}$ & $\mathrm{X}$ & & & 1 \\
\hline $\mathrm{X}$ & & $\mathrm{X}$ & & & & 1 \\
\hline $\mathrm{X}$ & & & & $\mathrm{X}$ & $\mathrm{X}$ & 1 \\
\hline $\mathrm{X}$ & & & & $X$ & & 2 \\
\hline $\mathrm{X}$ & & & & & & 1 \\
\hline & $\mathrm{X}$ & $\mathrm{X}$ & & $\mathrm{X}$ & & 2 \\
\hline & $\mathrm{X}$ & $\mathrm{X}$ & & & & 1 \\
\hline & $\mathrm{X}$ & & $\mathrm{X}$ & & & 1 \\
\hline & $\mathrm{X}$ & & & $\mathrm{X}$ & & 3 \\
\hline & $X$ & & & & & 1 \\
\hline & & $\bar{X}$ & $\bar{X}$ & $\bar{X}$ & $\bar{X}$ & 1 \\
\hline & & $\bar{X}$ & $\bar{X}$ & $\bar{X}$ & & 1 \\
\hline & & $X$ & $X$ & & & 3 \\
\hline & & $\bar{X}$ & & $\bar{X}$ & & 5 \\
\hline & & $\bar{X}$ & & & & 8 \\
\hline & & & $\mathrm{X}$ & $\mathrm{X}$ & $X$ & 1 \\
\hline & & & $X$ & $\mathrm{X}$ & & 3 \\
\hline & & & $X$ & & & 2 \\
\hline & & & & $\mathrm{X}$ & $\mathrm{X}$ & 1 \\
\hline & & & & $\mathrm{X}$ & & 11 \\
\hline
\end{tabular}

* The mark " $X$ " indicates the area in which at least one of the respondents' children lived. This table shows the residential distribution of each respondent's children. 
TABLE VII (B)

LIVING AREAS OF THE CHILDREN

\begin{tabular}{|l|l|c|}
\hline LIVING AREAS & NUMBER OF & PARENTS \\
& CHILDREN & RESPONSES \\
\hline with parents & one child & 8 \\
\hline in the same neighbor- & one child & 8 \\
hood as parents do & two children & 2 \\
\hline in Portland area & one child & 13 \\
& two children & 8 \\
& four children & 1 \\
& six children & 1 \\
\hline in Oregon state & one child & 11 \\
& two children & 3 \\
\hline in other state & one child & 19 \\
& two children & 12 \\
& four children & 1 \\
\hline in other country & one child & 4 \\
\hline not specified & one child & 5 \\
\hline & total number of \\
& children & 132 \\
\hline
\end{tabular}

to their children for help ( $C_{i}$ cirelli, 1981; Robinson and Thurnher, 1979; Sussman, 1965). However, these researchers did not further examine whether those parents received help from their offspring. The majority of the parents in this sample reported that when they were sick or when they got depressed, their children indeed helped them out or tried to comfort them (Table VIII).

TABLE VIII

CHILDREN'S ASSISTANCE TO PARENTS

\begin{tabular}{|l|l|l|}
\hline Children have done the following things: & Yes & No \\
\hline $\begin{array}{l}\text { 1. Help out the parents when they were } \\
\text { sic }\end{array}$ & $\begin{array}{l}86.5^{*} \\
(45) * *\end{array}$ & $\begin{array}{r}11.5 \\
(6)\end{array}$ \\
\hline $\begin{array}{l}\text { 2. Tried to comfort the parents when they } \\
\text { got depressed }\end{array}$ & $\begin{array}{l}71.2 \\
(37)\end{array}$ & $\begin{array}{l}26.9 \\
(14)\end{array}$ \\
\hline
\end{tabular}

*Percentage

**Number of Responses 
For the most part, the respondents' children seemed to have frequent contact with their parents. Twenty-eight out of forty-eight elderly parents indicated that their children had visited them within the week prior to the survey. The frequency of the children's visits was fairly consistent: of forty-nine parents, fifteen reported that the children came to see them more than once a week or weekly; eighteen said that the children visited them at least monthly. Children were likely to make phone calls more often than they visited their parents. About thirty-one percent of the parents received phone calls from their children more than once a week. Thirty-six parents received calls from their children within the week prior to the survey. However, when compared with visits and phone calls, correspondence was the method least used by children in contacting their parents. Only two parents received letters from their children on the day before the survey.

In regard to financial help, only four parents received help from their offspring in the week prior to filling out the questionnaires. Seventy-eight of the parents claimed that they had never received any financial aid from their offspring ( Table IX). Congruent results were reported by Robinson and Thurnher (1979), Sussman (1965), Sussman and Burchinal (1968), and Streib (1965), who noted the one-way flow of financial assistance from older generation to their offspring instead of from the younger generation to their 


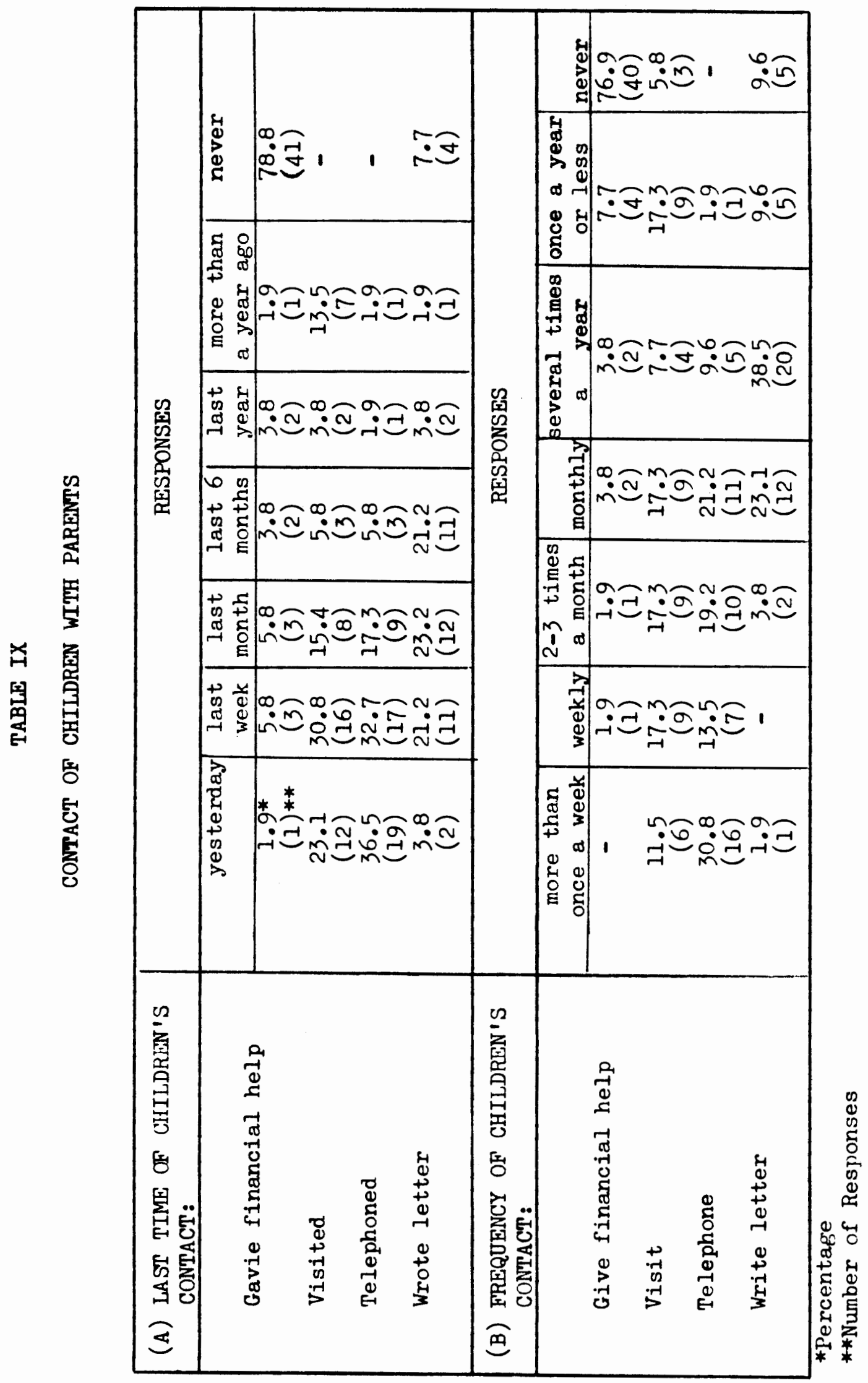


parents.

Four out of five old respondents felt that their offspring's attitudes toward their opinions were respectful or very respectful. The majority of the children sometimes accepted the responding parents' suggestions. When asked about the degree of satisfaction with the way their children treated them, more than half of the parents felt very satisfied, one third felt satisfied (Table $X$ ).

TABLE X

PARENTS' JUDGEMENTS ON CHILDREN'S ATTITUDES, CONFORMITY, AND RESPONSIBILITY

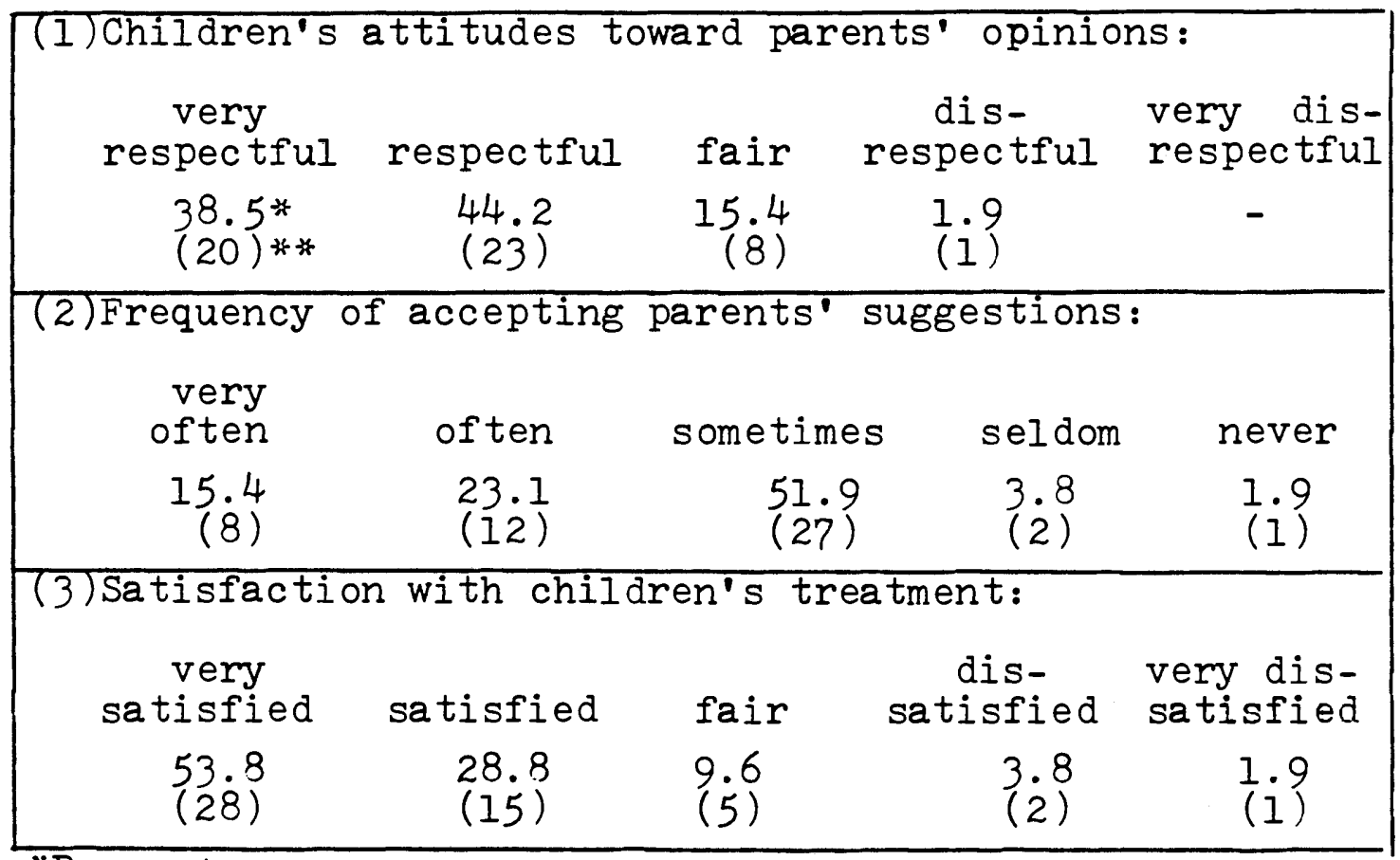

*Percentage

**Number of Responses 


\section{Filial Discrepancies}

According to the respondents' judgements, their offspring had fulfilled most of their filial expectations. The most valued filial behaviors--affectionate support, respect, and care--were consistently performed by the children. They also kept frequent contact with their older father or mother via telephone calls as the parents expected. The greater discrepancies were in the expectations of financial aid and frequent correspondence from the offspring. More than half of the parents expected their children to provide financial help, but more than three fourths of them reported that they had never received any aid from the children. Participants did not receive letters from their sons or daughters of ten either, even though seventy-five percent of them had at least one child living in some place other than in Portland area. on the whole, the participants tended toward the middle of the scales of their life satisfaction, filial expectations, and filial behavior. The level of filial expectations tended to be lower than the level of filial behavior. The distributions on each scale are presented in Table XI.

Filial discrepancies were the discrepant scores between expectations and behavior. It should be noted that to subtract values of Filial Expectations (FE) from Filial Behavior (FB) or of FB from FE would affect the direction of the relationship with life satisfaction; it also would determine which variable is higher than the other one. In this study, 
TABLE XI

LEVELS OF LIFE SATISFACTION, FILIAL EXPECTATIONS, AND FILIAI BEHAVIOR

\begin{tabular}{|c|c|c|c|}
\hline SCALES & $\begin{array}{c}\text { LIFE } \\
\text { SATISFACTION } \\
\end{array}$ & $\begin{array}{c}\text { FILIAL } \\
\text { EXPECTATIONS }\end{array}$ & $\begin{array}{c}\text { FILIAL } \\
\text { BEHAVIOR }\end{array}$ \\
\hline $1.0-1.4$ & - & $\begin{array}{l}3.8 * \\
(2) * *\end{array}$ & - \\
\hline $1.5-1.9$ & - & (i) & $\begin{array}{l}5.7 \\
(3)\end{array}$ \\
\hline $2.0-2.4$ & - & (i) & - \\
\hline $2.5-2.9$ & $\begin{array}{r}17.3 \\
(9)\end{array}$ & $\begin{array}{l}30.7 \\
(16)\end{array}$ & $\begin{array}{r}17.5 \\
(6)\end{array}$ \\
\hline $3.0-3.4$ & $\begin{array}{l}19.2 \\
(10)\end{array}$ & $\begin{array}{l}28.9 \\
(15)\end{array}$ & $\begin{array}{l}21.2 \\
(11)^{2}\end{array}$ \\
\hline $3.5-3.9$ & $\begin{array}{l}46.2 \\
(24)\end{array}$ & $\begin{array}{l}25.0 \\
(13)\end{array}$ & $\begin{array}{l}44.2 \\
(23)\end{array}$ \\
\hline $4.0-4.4$ & $\begin{array}{r}13.5 \\
(7)\end{array}$ & $?(4)$ & $\begin{array}{r}17.3 \\
(9)\end{array}$ \\
\hline $4.5-5.0$ & $\begin{array}{l}3.8 \\
(2)\end{array}$ & - & - \\
\hline \multicolumn{2}{|c|}{\begin{tabular}{l|l}
$\bar{X}($ mean $)$ & 3.6 \\
\end{tabular}} & 3.2 & 3.4 \\
\hline \multirow{2}{*}{\multicolumn{2}{|c|}{\begin{tabular}{ll|l} 
minimum & scores & 2.5 \\
maximum scores & 4.9 \\
\end{tabular}}} & 1.0 & 1.6 \\
\hline & & 4.3 & 4.4 \\
\hline
\end{tabular}

FE subtracted from $F B$ will be used to determine that Filial Discrepancies (FD) scores. The FD scores would be positive when the levels of FBare higher than the levels of FE; they would be negative when the levels of FB fall short of the levels of FE; and they would be zero when FB and FE are equal. Thus, the discrepancy scores between FE and FB ranged from -1.9 to 2.7. Twenty parents had levels of expectations higher than the levels of their children's perceived behavior. Five respondents had an equal level between expectations and behavior. The rest of them, twenty-seven, had lower levels 
of expectations than the levels of behavior (Table XII).

TABLE XII

FILIAL DISCREPANCIES (FB-FE)

\begin{tabular}{|c|c|c|c|c|c|c|c|}
\hline SCORE & $\mathrm{N}$ & SCORES & $\mathrm{N}$ & SCORE & $\mathrm{N}$ & SCORES & $\mathrm{N}$ \\
\hline \multicolumn{2}{|c|}{$(F B<F E)$} & -0.5 & 2 & \multicolumn{2}{|c|}{$(F B>F E)$} & 0.8 & 4 \\
\hline-1.9 & 1 & -0.4 & 1 & 0.1 & 2 & 1.0 & 1 \\
\hline-1.8 & 1 & -0.3 & 1 & 0.2 & 1 & 1.1 & 1 \\
\hline-1.6 & 2 & -0.2 & 5 & 0.3 & 2 & 1.2 & 1 \\
\hline-1.2 & 1 & -0.1 & 1 & 0.4 & 3 & 1.3 & 1 \\
\hline-1.1 & 2 & \multirow{2}{*}{\multicolumn{2}{|c|}{$(F B=F E)$}} & 0.5 & 1 & 1.4 & 2 \\
\hline-0.7 & 1 & & & 0.6 & 2 & 1.9 & 1 \\
\hline-.06 & 2 & 0 & 5 & 0.7 & 4 & 2.7 & 1 \\
\hline
\end{tabular}

Iife Satisfaction and the Independent Variables

The relationshiships between the overall life satisfaction scores and each of the items measured in the respondents' backgrounds, in the thirteen questions about filial expectations, and in the fourteen items of filial behavior were also examined by Pearsonian correlation coefficients (See Table XIII).

Among those items measured in the respondents' backgrounds, it was found that life satisfaction correlated significantly with number of children $(r=.37 ; p=.004)$, with the number of married children $(r=.42 ; p=.002)$, with the levels of interaction with their relatives $(r=.36 ; p=.005)$, as well as with their health condition $(r=.27 ; p=.028)$ and economic situation $(r=.33 ; p=.009)$. A correlation ap- 
proaching significance was found between the dependent variable and the interaction with friends $(r=.22 ; p=.074)$. A similar correlation obtained between the participants' previous occupation and the dependent variable $(r=.22 ; p=.102)$. There was very little association between the level of satisfaction in life and the respondents' age, gender, marital status, the number of unmarried children, living arrangement, retirement, or whether still working or not.

The correlation between life satisfaction and activity with relatives, health condition, and financial situation were relevent to the findings of previous research. However, the higher associations between the dependent variable and the number of children, between the dependent variable and the number of married children had not been found in the earlier studies. The interpretation of these correlations will be presented later in this analysis.

Except for expectations of living with children and of children's responsibility, there was a negative correlation relating life satisfaction and the rest of the measured expectations. However, most of variables in filial expectations had no significant relationship with life satisfaction. The only expectations with significant correlations were: long distance phone calls from the far away children $(r=-.37 ; p=.004)$; letters from the far away children $(r=-.26 ; p=.031)$; and local phone calls from nearby children $(r=-.25 ; p=.035)$. 
Items concerning filial behavior had the highest correlations with the dependent variable, except for two items regarding children's financial assistance to their parents, which were not significant. All other variables in the Filial Behavior Index had correlations with life satisfaction measuring between .25 and $.45(\mathrm{p}<.05)$ (Table XIII).

\section{HYPOTHESES}

The hypotheses of this study concern the relationship between life satisfaction of the elderly parents and (1) their filial expectations of their adult children, (2) the children's perceived filial behavior, and (3) the discrepancies between expectations and behavior. In order to clarify these relationships, Pears on correlation coefficients and Partial correlations were computed. Pearson's $r$ is a measure of association indicating the strength of the relationship between the dependent variable and each independent variable. Partial correlation provides a useful technique for uncovering a spurious relationship between the variables and for locating intervening variables. A spurious relationship refers to a correlation between two variables which is actually brought about by a third variable. If a third variable is found to be highly correlated with one or both variables, then the correlation between these two variables may disappear when the third variable is controlled (Bailey, 1978). 
TABLE XIII

CORRELATIONS OF LIFE SATISFACTION WITH ITEMS IN RESPONDENTS' BACKGROUNDS, FILIAL EXPECTATIONS, AND FILIAL BEHAVIOR

\begin{tabular}{|c|c|c|c|}
\hline $\begin{array}{l}\text { RESPONDENTS' } \\
\text { BACKGROUNDS }\end{array}$ & $r$ & $\begin{array}{l}\text { FILIAL } \\
\text { EXPECTATIONS }\end{array}$ & $r$ \\
\hline age & $-.13^{*}$ & living $w /$ & $.09 *$ \\
\hline gender & $-.03^{*}$ & & \\
\hline $\begin{array}{l}\mathrm{n} \text { of married } \\
\text { children }\end{array}$ & $\frac{.37}{p=.004}$ & $\begin{array}{l}\text { living near } \\
\text { parents** }\end{array}$ & $-.06 *$ \\
\hline $\begin{array}{l}n \text { of unmarried } \\
\text { children }\end{array}$ & $.03 *$ & $\begin{array}{l}\text { financial } \\
\text { help }\end{array}$ & $-.10 *$ \\
\hline retirement & $.03 *$ & $\begin{array}{l}\text { care } \\
\text { respon }\end{array}$ & $-.14 *$ \\
\hline occupation & $.22^{*}$ & telephone & -.25 \\
\hline working & $07 *$ & & \\
\hline situation & $J^{*}$ & visit & $-.17^{*}$ \\
\hline $\begin{array}{l}\text { living } \\
\text { situation }\end{array}$ & $.004 *$ & $\begin{array}{l}\text { long-distance } \\
\text { telephone }\end{array}$ & $\frac{-.37}{p=.004}$ \\
\hline $\begin{array}{l}\text { act with relig } \\
\text { groups }\end{array}$ & $\begin{array}{l}\text { rious } \\
.07 *\end{array}$ & letter & $\frac{-.26}{p_{=} .031}$ \\
\hline $\begin{array}{l}\text { act in senior } \\
\text { center }\end{array}$ & $4 *$ & $\begin{array}{l}\text { affection } \\
\text { support }\end{array}$ & $-.17 *$ \\
\hline \multirow{2}{*}{\multicolumn{2}{|c|}{$\begin{array}{l}\text { act in organi- } \\
\text { zations or } \\
\text { clubs }\end{array}$}} & respect & $-.06 *$ \\
\hline & & conformi ty & $-.14 *$ \\
\hline $\begin{array}{l}\text { act with } \\
\text { relatives }\end{array}$ & $\frac{.36}{p_{x} .005}$ & $\begin{array}{l}\text { purpose of } \\
\text { children }\end{array}$ & $-.18 *$ \\
\hline $\begin{array}{l}\text { act with } \\
\text { friends }\end{array}$ & $.22 *$ & $\begin{array}{l}\text { responsi- } \\
\text { bility }\end{array}$ & $.04 *$ \\
\hline $\begin{array}{l}\text { health } \\
\text { condition }\end{array}$ & $\frac{.27}{p=.028}$ & \multirow{3}{*}{\multicolumn{2}{|c|}{$\begin{array}{l}\text { **These items were } \\
\text { excluded from the } \\
\text { indexes of FEI and } \\
\text { FBI. }\end{array}$}} \\
\hline $\begin{array}{l}\text { financial } \\
\text { situation }\end{array}$ & $\frac{.33}{p=.009}$ & & \\
\hline *significa & & & \\
\hline
\end{tabular}

\begin{tabular}{|c|c|}
\hline $\begin{array}{l}\text { FILIAI } \\
\text { BEHAVIOR } \\
\end{array}$ & $r$ \\
\hline $\begin{array}{l}\text { living } \\
\text { arrangement }\end{array}$ & $\because \quad-.02 *$ \\
\hline care respon & $\frac{.29}{p=.018}$ \\
\hline $\begin{array}{l}\text { affection } \\
\text { support }\end{array}$ & $\frac{.32}{p=.012}$ \\
\hline $\begin{array}{l}\text { financial } \\
\text { help }\end{array}$ & $.23 *$ \\
\hline visit & $\frac{.36}{p=.006}$ \\
\hline telephone & $\frac{.35}{p=.006}$ \\
\hline letter & $\frac{.29}{p=.029}$ \\
\hline $\begin{array}{l}\text { frequency of } \\
\text { financial hel }\end{array}$ & $p$ \\
\hline $\begin{array}{l}\text { frequency of } \\
\text { visit }\end{array}$ & $\frac{.39}{\mathrm{p}=.003}$ \\
\hline $\begin{array}{l}\text { frequency of } \\
\text { telephone }\end{array}$ & $\frac{.35}{p_{s} .006}$ \\
\hline $\begin{array}{l}\text { frequency of } \\
\text { letter }\end{array}$ & $\frac{.25}{p=.046}$ \\
\hline respect & $\frac{.29}{p=.018}$ \\
\hline conformi ty & $\frac{.29}{p=.018}$ \\
\hline $\begin{array}{l}\text { responsi- } \\
\text { bility }\end{array}$ & $\frac{.45}{p=.001}$ \\
\hline
\end{tabular}


Expectations, Behavior, and Life Satisfaction

When items in FEI were combined as a scale, the correlation obtained between filial expectations $(F E)$ and life satisfaction ( $L S)$ was $r=-.24(p=.04)$. A slight trend was found in that the higher the parents' expectations of their children, the lower was the level of their life satisfaction. This finding was similar to Seelbach and Sauer's research findings (1977), which showed a significant relationship between high filial expectations and low morale among the elderly parents.

When items in FBI were looked as a scale, a highly significant correlation of $.52(p<.001)$ was found between filial behavior of the children and life satisfaction. This definite positive association between the two variables indicated that, if children are more responsible for and more filial toward their parents, by the parents' perception, greater satisfaction would result in the parents' lives. The data were inconsistent with previous studies which suggested that contact between parents and offspring had no, or an inverse, association with parental feelings of satisfaction in late life. It should be noted, however, that contact in this study was identified as a one-way practice from children to the parents instead of from parents to children or of two-way mutual contact.

The above statistical findings were consistent with the first hypothesis that life satisfaction of the parents 
is positively correlated with their children's filial behavior, but negatively correlated with their filial expectations of their children (Table XIV).

\section{TABLE XIV}

CORRELATIONS OF LIFE SATISFACTION WITH FILIAL EXPECTATIONS, FILIAL BEHAVIOR, AND FILIAL DISCREPANCIES

\begin{tabular}{|c|c|c|c|}
\hline VARIABLES & $\mathrm{FE}$ & $\mathrm{FB}$ & FD \\
\hline LS & $\begin{array}{r}-.24 \\
p=.04\end{array}$ & $.52^{*}$ & $.53^{*}$ \\
\hline $\mathrm{FE}$ & & $\begin{array}{c}-.04 \\
p=.402\end{array}$ & $-.74 *$ \\
\hline FB & & & $.70 *$ \\
\hline
\end{tabular}

Filial Discrepancies and Life Satisfaction

In testing the second hypothesis of this study, it was found that the relationship between life satisfaction and filial discrepancies was also statistically significant: $r=.53(p<.001)$. This important finding supported the second hypotheses: if children's perceived filial behavior towards their parents exceeds their parents' expectations, the parents will have more satisfaction in their lives than those parents whose expectations of their children exceeded their children's actual perceived behavior towards them (Table XIV). 


\section{Multiple and Partial Correlations}

The major variables were analyzed using multiple correlation, a statistical technique for measuring the relation between one dependent variable and the combined effect of a number of independent variables. The multiple correlation relating expectations and behavior with life satisfaction was quite strong, $R_{L S \cdot F E ~ F B}=.56(p<.05)$, indicating that filial expectations and filial behavior together have a significant relationship with life satisfaction.

The square of the multiple correlation serves a major purpose in indicating the proportion of variance in one dependent variable explained by several independent variables. In this case, when $R$ was squared, $R^{2} L S \cdot F E F B=\cdot 32$. It indicated that parents' filial expectations and children's filial behavior together account for thirty-two percent of the variation in parents ' life satisfaction.

Table XIV presents the pattern of relationships among filial expectations, filial behavior, filial discrepancies, and life satisfaction. The relationship between behavior and expectation was negligibly negative $(r=.04)$. The association between discrepancies and expectations was significantly negative $(r=-.74 ; p<.001)$, while that between discrepancies and behavior was significantly positive $(r=.70 ; p<.001)$. Further, there was a moderate (-.24) negative association between expectation and life satisfaction, but both behavior and discrepancies were strongly associated with life satis- 
faction. Therefore, it is assumed that filial behavior was the most influential variable affecting not only life satisfaction but also the relationship between life satisfaction and filial discrepancies.

When first-order partials were used to explore further the relationships between the dependent variable and each independent variable (Table XI), it was found that, when the effects of filial behavior were taken into account, the correlation between life satisfaction and filial discrepancies dropped substantially, from .53 to a still significant .27 $(p<.05)$. If filial expectations were controlled, the correlation between life satisfaction and filial discrepancies was unaffected, remaining at .53 . When controlling for both expectations and behavior, the correlation between life. satisfaction and filial discrepancies also dropped greatly from the original correlation, .53 to .25 $(\mathrm{p}=.04)$. The other first-order partial correlations showed values similar to the initial zero-order correlations. These results indicate that filial behavior had a major influence on the life satisfaction and that a major part of the effect of discrepancy on life satisfaction is due to variation in behavior. However, some variance is explained by the difference between expectation and behavior when the independent effects of those variables are controlled.

Thus far, the variables correlating most with life satisfaction have been filial behavior and filial discrepan- 
TABLE XV

PARTIAL CORREIATIONS AMONG

MAJOR VARIABLES

\begin{tabular}{|c|c|c|c|}
\hline $\begin{array}{l}\text { Zero-order } \\
\text { correlations }\end{array}$ & $\mathrm{FE}$ & FB & FD \\
\hline LS & $-.24 *$ & $.52 * *$ & $.53 * *$ \\
\hline $\begin{array}{l}\text { First-order } \\
\text { partials }\end{array}$ & $\mathrm{FE}$ & FB & FD $\quad F D$ \\
\hline controlling for & FB & $\mathrm{FE}$ & $\mathrm{FE} \quad \mathrm{FB}$ \\
\hline LS & $-.26 *$ & $.53 * *$ & $.53 * .27 *$ \\
\hline $\begin{array}{l}\text { Second-order } \\
\text { partials }\end{array}$ & & FD & \\
\hline controlling for & & FE AND & FD \\
\hline LS & & $.25^{*}$ & \\
\hline
\end{tabular}

cies. However, these correlations could actually be spurious, if their relationships were affected by a third variable. Therefore, an examination was made of the relationship between each of variables in the respondents' backgrounds and (1) overall life satisfaction, (2) level of filial expectations, (3) level of filial behavior, and (4) level of filial discrepancies.

Recalling the measures of the respondents' backgrounds and their life satisfaction, five variables were found to be positively correlated with life satisfaction: (1) number of 
children, (2) number of married children, (3) interaction with relatives, (4) health condition, and (5) financial situation.

Parents' occupational level appeared to have a moderately negative impact on their expectations of children, $r=-.42(p=.006)$. One could conclude that the higher the parents' previous occupational position, the lower the expectations these parents had for their adult children. Parents' health condition and economic situation also appeared to have a slightly negative impact on their expectations. In as much as occupational rating, health, and financial condition all typically related to socioeconomic position, it appears that parents of higher social status tended to have lower filial expectations--a somewhat surprising finding. Also unexpected was the negative correlation, $-.31(p=.014)$ between health and life satisfaction and that between economic situation and the dependent variable, -.30 ( $\mathrm{p}=.017)$ (Table XVI).

The relationship between filial behavior and interaction with friends was found to be $r=.27(p=.037)$. If the parents interacted with their friends a lot, their children's behavior was perceived to be more filial. Parents' selfrated heal th and financial situations were not related to their perception of their children's filial behavior. However, both variables were important in affecting the filial discrepancies. That is, the respondents who had better health and who were economically better off felt their chil- 


\section{TABLE XVI}

CORREIATIONS OF RESPONDENTS' BACKGROUNDS WITH FILIAL EXPECTATIONS, FILIAL BEHAVIOR, AND FILIAL DISCREPANCIES

\begin{tabular}{|c|c|c|c|}
\hline $\begin{array}{l}\text { RESPONDENTS' } \\
\text { BACKGROUNDS }\end{array}$ & $\begin{array}{c}\text { FILIAI } \\
\text { EXPEC TATIONS } \\
\end{array}$ & $\begin{array}{c}\text { FILIAI } \\
\text { BEHAVIOR }\end{array}$ & $\begin{array}{c}\text { FILIAI } \\
\text { DISCREPANCIES }\end{array}$ \\
\hline age & $.20 *$ & $-.10 *$ & $-.21 *$ \\
\hline marital status & $-.01 *$ & $.05 *$ & $.03 *$ \\
\hline number of children & $-.12 *$ & $\frac{.48}{p<.001}$ & $\frac{.41}{p=.001}$ \\
\hline $\begin{array}{l}\text { number of married } \\
\text { children }\end{array}$ & $-.21 *$ & $\frac{.40}{p=.003}$ & $\frac{.44}{p=.001}$ \\
\hline $\begin{array}{l}\text { number of unmarried } \\
\text { children }\end{array}$ & $-.15^{*}$ & $-.20^{*}$ & $-.03 *$ \\
\hline occupation & $\frac{-.42}{p=.006}$ & $.03 *$ & $p=.040$ \\
\hline working situation & $-.04 *$ & $-.02 *$ & $.01 *$ \\
\hline living situation & $.07 *$ & $.14 *$ & $.04 *$ \\
\hline $\begin{array}{l}\text { act with religious } \\
\text { groups }\end{array}$ & $.11^{*}$ & $.05 *$ & $.05 *$ \\
\hline act in senior center & $-.10 *$ & $.11 *$ & $.15^{*}$ \\
\hline $\begin{array}{l}\text { act in organizations } \\
\text { or clubs }\end{array}$ & $.15^{*}$ & $.19 *$ & $.02 *$ \\
\hline act with relatives & $-.10 *$ & $.18 *$ & $.20 *$ \\
\hline act with friends & $.10 *$ & $\frac{.27}{p=.037}$ & $.10 *$ \\
\hline health condition & $\frac{-.31}{p=.014}$ & $.10 *$ & $\frac{.27}{p=.028}$ \\
\hline financial situation & $\frac{-.30}{p=.017}$ & $.15^{*}$ & $\frac{.30}{p=.018}$ \\
\hline
\end{tabular}

\footnotetext{
*Significance level>.05
} 
dren's behavior toward them were more filial than they expected of their children. The correlation were .27 $(p=.028)$ and $.30(p=.018)$, respectively.

The findings revealed that the number of children and of married children had a significant relationship with their perceived filial behavior and with the discrepancies between expectations and behavior. This indicated that parents who had more children perceived their children's behavior toward them as more filial than their expectations of their offspring. Moreover, the number of children and the number of married children also had a very definite positive relationship with life satisfaction. The data indicated that there was a higher degree of congruence between parents' expectations and perceived children's behavior among those parents who had more children and who had more married children.

This congruence is due to several factors. The more children the respondents had, the more chances that at least one of their children would fulfill their filial expectations. The fewer children the parents had, the less chances that parents filial expectations would be fulfilled. Further, the findings indicated that if the children were married, they were more filial to their parents than unmarried children. One interpretation might be that the relationship was due to the fact that most married children had children of their own. Seventy-five percent of the total old American population has living grandchildren (Atchley, 1980). Grown 
children raising their own children might realize how difficult it was for their parents to raise them. From this realization, they might try to repay their parents' raising effort by being more filial to their parents. Another interpretation for the strong relationships between the number of married children and their filial behavior might be, as Hess and Waring (1978) suggested, that middle-age children attempt to set a model for their own children. If they take care of their own aged mother and/or father, they might expect such care in return for themselves from their own children. These interpretations oppose to Kalish's (1967) analysis of the contunity of children's responsibility being passed on to the next generation instead of returning back to their own parents. Thus, al though there were no questions regarding grandchildren of the respondents--because according to Atchley (1980), grandchildren play a less important role for their grandparents--this study suggested that grandchildren may play an "indirect important role" for their grandparents. In short, this research strongly indicated the importance of children in the lives of their elderly parents, in contrast to the study by Glenn and Mclanahan (1981) which found that having children made no contribution to the happiness or satisfaction of parents in late middle age and beyond.

The above findings showed that seven variables in the respondents' backgrounds were related to either parents' life 
satisfaction, their filial expectations, their perceptions of their children's filial behavior, or their filial discrepancies. The variables were: (1) number of children, number of married children, (3) occupation, (4) interaction with relatives, (5) interaction with friends, (6) health condition, and (7) financial situation. Except for variables regarding the number of children, the rest of the characteristics had been found in previous research to have effects on the life satisfaction of elderly people and on the parent-child relationship in late life.

The relationships between life satisfaction and the expectation, behavior, and discrepancy scales were examined further utilizing partial correlation techniques to control for the effect of the various background variables. Thus, the correlations contained in the following tables include zero-order correlations and first-order partials.

When comparing the zero-order correlations with the first-order partials, number of children and of married children were found to have a strong effect on the relationships between life satisfaction and filial behavior, and between life satisfaction and filial discrepancies. The first-order partials showed a substantial drop from the initial correlations. However, correlations between the dependent variable and the independent variables were still significant. Occupation had only a slight influence on the association between life satisfaction and filial expecta- 
tions. Interaction with relatives and interaction with friends had little impact on the strength of relationship of these variables.

Both health and financial situation had some effect on the relationships between life satisfaction and filial expectations, and between life satisfaction and filial discrepancies, with financial situation having a greater effect than health on the relationship between life satisfaction and expectations.

The partial correlations showed that the relationships between life satisfaction and each of the independent variables were not spurious. Al though number of children, number of married children, financial situation, health, and occupation effected the relationships, the effect was not great enough to explain the significance of the correlations (Table XVII).

In conclusion, the relationships between life satisfaction and each of the independent variables were not affected by respondents' backgrounds but primarily by their children's filial behavior.

Activity vs Disengagement

When the variables "participation in religious groups," "participation in senior center," "participation in clubs or organizations," "interaction with relatives," and "interaction with friends" are put together as a single variable-activity--, the correlation between it and life satisfaction 
TABLE XVII

ZERO-ORDER AND FIRST-ORDER

PARTIAL CORRELATIONS

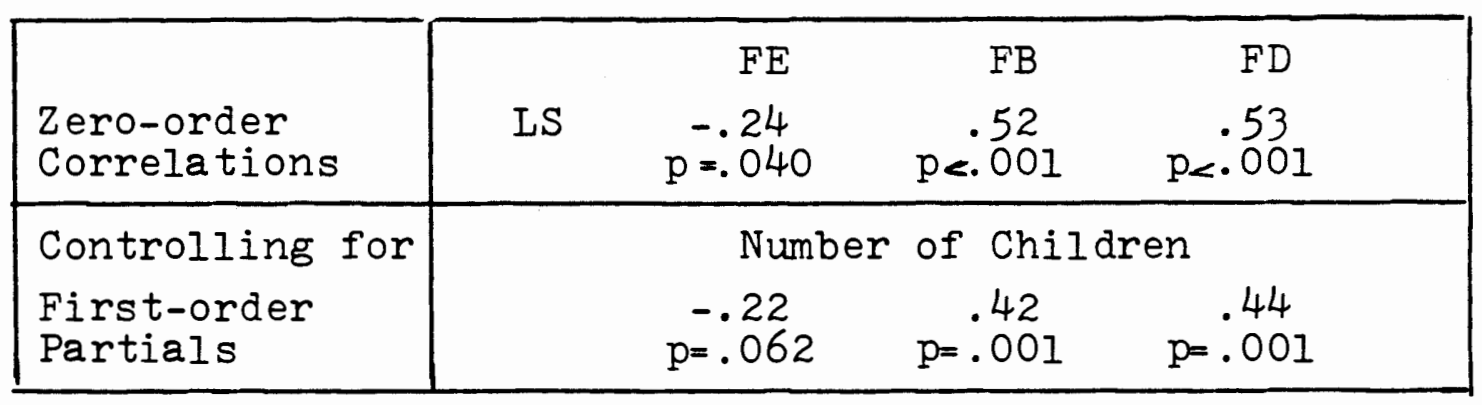

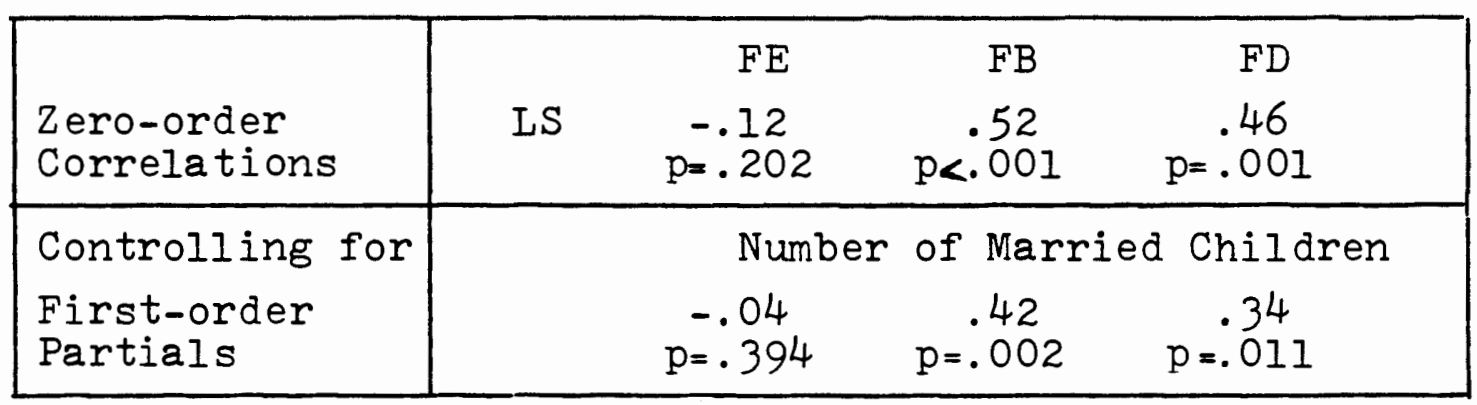

\begin{tabular}{|c|c|c|c|}
\hline $\begin{array}{l}\text { Zero-order } \\
\text { Correlations }\end{array}$ & LS & $\begin{array}{c}F E \\
-.42 \\
p=.006\end{array}$ & $\begin{array}{r}\text { FD } \\
.70 \\
\mathrm{p}<.001\end{array}$ \\
\hline Controlling for & \multicolumn{3}{|c|}{ Occupation } \\
\hline $\begin{array}{l}\text { First-order } \\
\text { Partials }\end{array}$ & & $\begin{array}{l}-.37 \\
p=.015\end{array}$ & $\begin{array}{c}.68 \\
p_{<} .001\end{array}$ \\
\hline
\end{tabular}

\begin{tabular}{|c|c|}
\hline $\begin{array}{l}\text { Zero-order } \\
\text { Correlations }\end{array}$ & $\begin{array}{cc} & F E \\
\text { LS } \quad & .22 \\
\mathrm{p}=.062\end{array}$ \\
\hline $\begin{array}{l}\text { Controlling for } \\
\text { First-order } \\
\text { Partials }\end{array}$ & $\begin{array}{l}\text { Activity with Relatives } \\
.20 \\
p_{x} .087\end{array}$ \\
\hline
\end{tabular}


TABLE XVII

\begin{tabular}{|c|c|}
\hline $\begin{array}{l}\text { Zero-order } \\
\text { Correlations }\end{array}$ & $\begin{aligned} & F B \\
& \text { LS } \quad .44 \\
& \mathrm{p}=.001\end{aligned}$ \\
\hline $\begin{array}{l}\text { Controlling for } \\
\text { First-order } \\
\text { Partials }\end{array}$ & $\begin{array}{l}\text { Activity with Friends } \\
.40 \\
p=.004\end{array}$ \\
\hline
\end{tabular}

\begin{tabular}{|c|c|c|c|}
\hline $\begin{array}{l}\text { Zero-order } \\
\text { Correlations }\end{array}$ & LS & $\begin{aligned} F E \\
-.28 \\
p=.025\end{aligned}$ & $\begin{array}{r}F D \\
.54 \\
\mathrm{p}<.001\end{array}$ \\
\hline Controlling for & \multicolumn{3}{|c|}{ Health Condition } \\
\hline $\begin{array}{l}\text { First-order } \\
\text { Partials }\end{array}$ & & $\begin{array}{l}-.21 \\
p=.071\end{array}$ & $\begin{aligned} & .51 \\
& \mathrm{p}<.001\end{aligned}$ \\
\hline
\end{tabular}

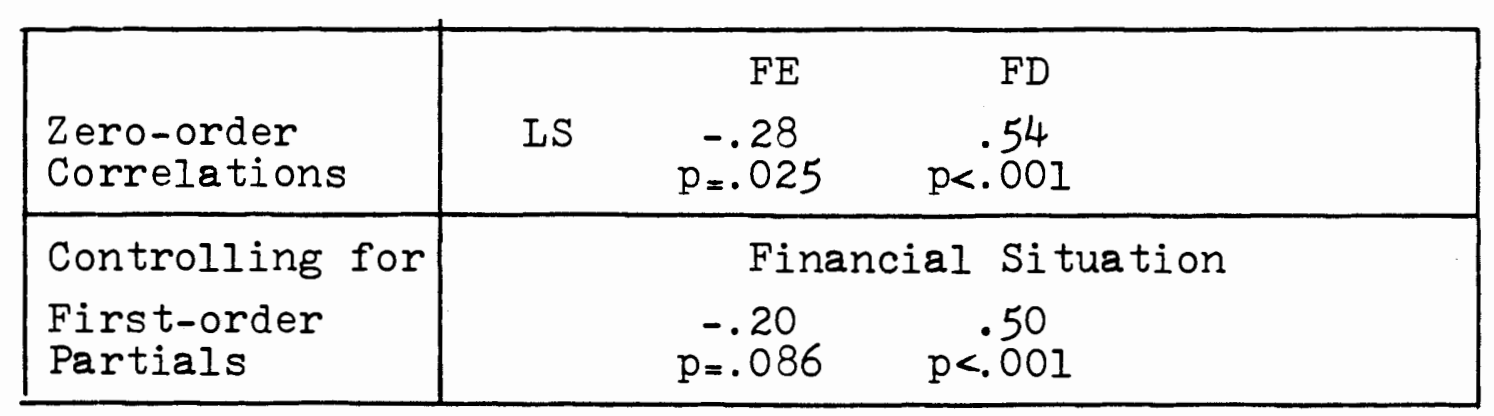


was also found to be significant: $r=.28(p=.022)$.

This finding supported Tobin and Neugarten's study (1961), which found that a higher level of life satisfaction occurred more often with persons who were socially active and involved than with persons who were inactive and uninvolved. Their findings further showed that, with increasing age, engagement rather than disengagement was more strongly associated with life satisfaction. The findings reported in the earlier part of this chapter also indicated that, as age advanced, people would still be active in some social activities, particularly in activities with religious groups, in activities held by organizations or clubs, and in activities with relatives.

Moreover, this study had different results from previous research which suggested that parents would have a higher level of satisfaction in lives if they were physically and spiritually disengaged from their adult children. The data of this research suggest that the more the contact of children with their parents, the higher the life satisfaction of the parents. Table XIII has shown that children's filial behavior in terms of visits, telephone calls, and correspondence significantly and positively correlated with parents satisfaction with their lives. Therefore, lower level of satisfaction among the elderly parents were associated with less engagement of their children with them.

Instead of disengagement theory, activity theory was 
supported as an accuration depiction of both life satisfaction and the parent-child relationship in old age. In other words, engagement appeared to be the most applicable theory to parents in the successful aging and in the generational relations studies.

\section{CONCLUSION}

In summary, there are three hypotheses in this study. It was hypothesized that life satisfaction of elderly parents is negatively correlated with the parents' filial expectations of their children, but positively correlated with children's filial behavior, and it is correlated with filial discrepancies--the discrepancies between expectations and behavior. The results demonstrated that a genuine positive relationship exists between the life satisfaction and filial behavior and filial discrepancies. A genuine negative relationship also is found between life satisfaction and filial expectations. The analysis of data, therefore, strongly supported all the hypotheses. However, the data did not support the application of disengagement theory to the interaction of adult children with their aging parents.

In conclusion, adult children are still important in their parents lives. There are discrepancies between old parents' expectations of their offspring and the offspring's behavior towards the parents. These discrepancies affect parental life satisfaction. If children are perceived to be 
more filial than they are expected to be, their parents' life satisfaction will be higher than that of parents whose children are expected to be more filial than they are perceived to be in behavior. 


\section{CHAPTER V}

\section{DISSCUSION AND CONCLUSION}

The preceding chapter presented the impact of the parent-child relationship on the psychological well-being of elderly parents. The collected data clearly revealed that there were some discrepancies between parental normative expectations for their grown children and the children's actual behavior in fulfilling the expectations, and that there was a higher level of life satisfaction among parents who perceived their children's behavior to be more filial toward them than they expected.

Three qualifications should be taken into account in connection with this major finding.

(1) In this research, the parent-child relationship was examined from the standpoint of filial discrepancies: parents' expectations were compared to the children's behavior. It should be noted that the comparison was based upon the parents' subjective feelings or perceptions about their children's behavior. Therefore, the perceived behavior, rather than the actual behavior of the grown children showed influence on the elderly parents' psychological well-being.

(2) According to the respondents, most of their expectations had been fulfilled by their children. However, 
Johnson and Bursk (1977) found that elderly parents often evaluated the relationship with their offspring higher than their children did. Parents may have overrated their children's filial behavior when they responded to the Filial Behavior Index. As a result, perhaps the parents were not actually treated as well as they expected to be treated by their children.

(3) It was found that the number of children had a significant relationship with the parents' psychological well-being. An interpretation of this relationship might be that the more children the parents had, the more chances they would have of being satisfied with at least one of their children. As a result of this satisfaction, they would have higher satisfaction with their lives in general. However, the chance they would be dissatisfied with at least one is also increase. In any case, parents were not requested to evaluate each individual child's behavior separately; the perceived behavior was the cumulative evaluation from the parents for all their offspring.

These qualifications help one interpret the results of the research. Nevertheless, they also show the deficiencies in this study.

(1) This research has emphasized reciprocal role relationships between the generations through the concept of parental expectations and children's filial obligations. The study group indicated the strength of their expectations 
for their offspring's affection, respect, and care. However, whether the obligatory ties were likely to be felt by the children for their parents as Bengtson and Black (1973) described was not explored. Do children nowadays really have feelings of obligation toward their parents? Is filial responsibility still a countermyth as Cicirelli (1981) suggested? Whether the younger generation would be willing to provide adequate and effective help to their aging parents when the parents needs become greater in the future was unexplored.

(2) Only one-way interaction of children with their older parents was examined from the standpoint of parents' perceptions. Examination from the viewpoint of both generations on their two-way interactions might more accurately predict parental life satisfaction. Would this two-way examination be a better way to study the parent-child relationships in late life?

However, there are numberous difficulties in locating an adequate sample of elderly parents and their offspring in the same study. A parent may have more than one child through different marriages. Their children may not be born with the same parents, and they might not live in the same area as their parents or their siblings. Even if offspring were included in the sample, data validity problems will remain: would the offspring actually respond about their real behavior and attitudes toward their old parents? These 
difficulties or issues can be regarded as suggestions for future research.

(3) The filial discrepancies were determined by the comparisons between the corresponding items in both the expectational index and the behavioral index. Some corresponding items were eliminated from further use in comparison because of difficulty in measureing them--especially the questions regarding children's living area. Instead of asking about the areas in which they lived, questions should have been asked regarding the distance of their residences from their parents', because living distance is much more quantitatively specific than the living area. Moreover, distance is an important variable having an effect on their certain behavior toward parents, such as frequencies of visit, phone call, or correspondence. In this study, for instance, living in Vancouver, Washington is categorized as "living in another state." But its distance from Portland, in which the parents are living, is much less than that of other cities within the same state. Therefore, the third deficiency in this research is due to the design of the instrument.

Since both the expectational index and the behavioral index did not have enough questions to include all varieties of parents' expectations for their children and children's behavior toward their parents, in further research both indexes of filial expectations and filial behavior should 
add more corresponding information about children and further information about their future responsibilities for their parents. Moreover, the items in the indexes should be measured as quantitatively as possible so that filial discrepancies can be determined more accurately.

From a gerontological perspective, two implications are relevant to the significance of the findings:

(I) Despite a thirty year debate between the two leading theories of aging, both disengagement and activity perspectives agree that participation in activities has an impact on the psychological well-being of aging people. Disengagement theory, which has received more criticism than activity theory, notices the mutual withdrawal process of aging persons and the society. Activity theory, favored by this study, however, does not consider being active as a mutual process. It focuses almost entirely on the single process of aging individual's participation in varied activities. If in fact the elderly's engagement with others can bring a higher life satisfaction, then others' engagement with them also may have the same result.

If the parents perceptions of their children's behavior is close to the actual behavior, this study can conclude that the more frequent the emotional and behavioral engagement of children with their parents, the higher the life satisfaction on the parents. One clear implication from this conclusion is that the engagement of others in the aging individu- 
al's life is crucial to his or her psychological well-being.

(2) The life satisfaction approach holds that people have aged successfully if they are satisfied with their present and past lives. The degree of satisfaction is based on their own personal judgement. Likewise, the assessments of their children's filial behaviors toward them are based on the parents' judgement. Since the level of filial behavior and the level of life satisfaction were significantly and strongly related, the second implication of this finding is that those who are satisfied with their children's behavior towards them are also satisfied with their lives in general.

In conclusion, this research is clear in showing that: (1) parents' higher expectations for their grown children lead to their own lower life satisfaction and higher filial behavior of children toward their parents results in greater satisfaction of the parents with their lives; (2) a higher level of life satisfaction occurs for the parents who perceive their children's behavior to be more filial toward them than they expected. Put differently, this research is clear in showing that there are discrepancies between normative expectations and perceived behavior. These filial discrepancies influence the parents' psychological well-being. It is children's filial behavior that most strongly affects parents' life satisfaction. It also had a major influence on the relationship between life satisfaction and filial discrepancies. 
In exploring successful aging and parent-child relationships in old age, this research tends to support the activity theory, since the data demonstrate that the more the filial involvement of children with their aged parents, the higher the life satisfaction for the parents. This adds more dimention to the activity theory--both the aging individual's engagement with others and other's engagement with him or her can result in a higher level of life satisfaction. The life satisfaction approach to both aging and generational relations is also supported by the present study. It appears that, if elderly parents are satisfied with their adult children's behavior toward them, they are satisfied with their lives in general as well, or visa versa. 


\section{A SELECTED BIBLIOGRAPHY}

Adams, D. 1969. "Analysis of a Life Satisfaction Index," Journal of Gerontology 24:470-474.

Adams, D. 1971. "Correlates of Satisfaction Among the Elderly," Gerontologist 11:64-68.

Arling, G. 1976. "The Elderly Widow and Her Family, Neighbors and Friends," Journal of Marriage and the Family 38:759-768.

Atchley, R. 1980. The Social Forces in Later Life: An Introduction to Social Gerontology. Belmont, California: Wadsworth Publishing Company.

Backman, L., and B. Houser. 1982. "The Consequences of Childiess on the Social-Psychological Well-being of older Women," Journal of Gerontology 37:243-250.

Bailey, K. 1978. Methods of Social Research. New York: The Free Press.

Bell, T. 1967. "The Relationship Between Social Involvement and Feeling Old Among Residents in Homes for the Aged," Journal of Gerontology 22:17-22.

Bengtson, V. 1979. "Research Perspectives on Intergenerational Interaction," pp. 37-57 in P. Ragan (ed.), Aging Parents. Los Angeles: The University of Southern California Press.

Bengtson, V., and K. Black. 1973. "Intergenerational Relations and Continuities in Socialization," pp. 207-234 in P. Baltes and K. Schaie (eds.), Life Span Development Psychology: Personality and Socialization. New York: Academic Press.

Blalock, H. 1960. Social Statistics. New York: McGrawHill Book Company.

Brody, E. 1970. "The Etiquette of Filial Behavior," Aging and Human Development 1:87-94.

Bultena, G., and R. Oyler. 1971. "Effects of Health on Disengagement and Morale," Aging and Human Development 2:142-148. 
Cavan, S., E. Burgess, R. Havighurst, and H. Goldhamer. 1949. Personal Adjustment in 01d Age. Chicago: Science Research Associates, Inc.

Christensen, H. 1964. Handbook of Marriage and the Family. Chicago: Rand McNally and Company.

Cicirelli, V. 1981. Helping Elderly Parents: The Role of Adult Children. Boston: Auburn House Publishing Company.

Conner, K., E. Powers, and G. Bultena. 1979. "Social Interaction and Life Satisfaction: An Empirical Assessment of Late-Iife Pattern," Journal of Gerontology 34:116121 .

Cumming, E., and W. Henry. 1961. Growing 01d: The Process Of Disengagement. New York: Basic Books.

Edwards, J., and D. Klemmack. 1973. "Correlates of Life Satisfaction: A Re-examination," Journal of Gerontology $28: 497-502$.

Ellison, D. 1969. "Alienation and the Will to Live," Journal of Gerontology 24:361-366.

George, L., and L. Bearon. 1980. Quality of Life in Older Person: Meaning and Measurement. New York: Human Sciences Press, Inc.

Glenn, N., and S. Mclanahan. 1981. "The Effects of Offspring on the Psychological Well-being of Older Adults," Adults," Journal of Marriage and the Family 43:409421 .

Goffman, E. 1961. Encounters. Indianapolis: Bobbs-Merrill.

Graney, M. 1975. "Happiness and Social Participation in Aging," Journal of Gerontology 30:701-706.

Hess, B., and J. Waring. 1978. "Parent and Child in Later Life: Rethinking the Relationship," pp. 241-273 in R. Lerner and G. Spanier (eds.), Child Influences on Marital and Family Interaction: A Life-Span Perspective. New York: Academic Press.

Johnson, E., and B. Bursk. 1977. "Relationships Between the Elderly and Their Adult Children." Gerontologist $17: 90-96$. 
Kalish, R. 1967. "Of Children and Grandfathers: A Speculative Essay on Dependency," Gerontologist 7:65-69.

Kerckhoff, A. 1965. "Nuclear and Extended Family Relationships: A Normative and Behavioral Analysis," pp. 93112 in E. Shanas and G. Streib (eds.), Social Structure and the Family: Generational Relations. Englewood Cliff, New Jersey: Prentice-Hall.

Kerckhoff, A. 1966. "Family Patterns and Morale in Retirement," pp. 173-192 in I. Simpson and J. Mckinney (eds.), Social Aspects of Aging. Durhan, North

Carolina: Duke University Press.

Larson, R. 1978. "Thirty Years of Research on the Subjective Well-being of Older Americans," Journal of Gerontology 33:109-125.

Lee, G., and E. Ellithorpe. 1982. "Intergenerational Exchange and Subjective Well-being Among the Elderly," Journal of Marriage and the Family $44: 217-224$.

Lee, G. 1978. "Marriage and Morale in Late Life," Journal of Marriage and the Family 40:131-139.

Lemon, B., V. Bengtson, and J. Peterson. 1972. "An Exploration of the Activity Theory of Aging: Activity Types and Life Satisfaction Among In-movers to A Retirement Community," Joumal of Gerontology 27:511-523.

Lohmann, N. 1977. "Correlations of Life Satisfaction, Morale, and Adjustment Measures," Journal of Gerontology 32:73-75.

Louis Harris and Associates. 1975. The Myth and Reality of Aging in America. Washington D.C.: National Council on Aging.

Lowenthal, M., and D. Boler. 1965. "Voluntary vs Involuntary Social Wi thdrawal," Journal of Gerontology 20: 363-371.

Maddox, G., and C. Eisdorfer. 1962. "Some Correlates of Activity and Morale Among the Elderly," Social Forces $40: 254-260$.

Maddox, G. 1963. "Activity and Morale: A Longitudinal Study of Selected Elderly Subjects," Social Forces 42:195-204. 
Maddox, G. 1973. "Growing 01d: Getting Beyond and Stereotypes," pp. 5-16 in R. Boyd and C. Oakes (eds.),

Foundations of Practical Gerontology. Columbia, South Carolina: University of South Carolina Press.

Markides, K., and H. Martin. 1978. "A Causal Model of Life Satisfaction Among the Elderly," Journal of Gerontology $34: 86-93$.

Martin, W. 1973. "Activity and Disengagement: Life Satisfaction of In-movers into A Retirement Community," Gerontologist 13:224-227.

Medley, M. 1976. "Satisfaction with Life Among Persons Sixty-five Years and Older," Journal of Gerontology $31: 448-455$.

National Opinion Research Center. 1975. National Data Program for the Social Sciences: Codebook for the Spring 1975. General Social Survey, July, 1975. University of Chicago.

Neugarten, B. 1975. "The Future of the Young-0ld," Gerontologist $15: 4-9$.

Neugarten, B. R. Harvighurst, and S. Tobin. 1961. "The Measurement of Life Satisfaction," Journal of Gerontology $16: 134-143$.

Palmore, E. 1979. "Predictors of Successful Aging," Gerontologist 19:427-431.

Palmore, E., and C. Luikart. 1972. "Health and Social Factors Related to Life Satisfaction," Journal of Health and Social Behavior 13:68-80.

Peterson, J. 1979. "The Relationships of Middle-aged Children and Their Parents," pp. 27-36 in P. Ragan ( (ed.), Aging Parents. California: The University of Southern California Press.

Preston, C., and K. Gudiksen. 1966. "A Measure of SelfPerception Among Older People," Journal of Gerontology $21: 63-71$.

Riley, M., and A. Foner. 1968. Aging and Society. Volume One: An Inventory of Research Findings. New York: Russell Sage Foundation.

Robinson, B., and M. Thurnher. 1979. "Taking Care of Aged Parents: A Family Cycle Transition," Gerontologist 19:586-593. 
Rosow, I. 1965. "The Aged, Family, and Friends " Social Security Bulletin 28 (11):18-20.

Rubenstein, D. 1971. "An Examination of Social Participation Found Among A National Sample of Black and White Elderly," Aging and Human Development 2:172-188.

Schorr, A. 1960. "Filial Responsibility in the Modern American Family," Social Security Admission. Washington D.C.

Seelbach, W., and W. Sauer. 1977. "Filial Responsibility Expectations and Morale Among Aged Parents," Gerontologist $17: 492-499$.

Shanas, E. 1961. Family Relationships of Older People. National Opinion Research Center University of Chicago. Health Information Foundation Research Series \#20.

Shanas, E. 1979a. "Social Myth as the Hypothesis: The Case of the Family Relations of 0ld People." Gerontologist $19: 3-9$.

Shanas, E. 1979b. "The Family as a Social Support System in 01d Age," Gerontologist 19:169-174.

Shanas, E., and G. Streib. 1965. Social Structure and the Family: Generational Relations. Englewood, New Jersey: Prentice-Hall.

Simos, B. 1973. "Adult Children and Their Aging Parents," Social Work: 18:78-85.

Spreitzer, E. and E. Snyder. 1974. "Correlates of Life Satisfaction Among the Aged," Journal of Gerontology $29: 454-458$.

Streib, G. 1965. "Intergenerational Relations: Perspectives of the Two Generations on the Older Parent," Journal of Marriage and the Family $27: 469-476$.

Sussman, M. 1953. "The Help Pattern in the Middle Class Family," American Sociological Review 18:22-28.

Sussman, M. 1965. "Relationships of Adult Children with Their Parents in the United States," pp. 62-92 in E. Shanas and G. Streib (eds.), Social structure and the Family: Generational Relations. Englewood, New Jersey: Prentice-Hall. 
Sussman, M., and L. Burchinal. 1968. "Kin Family Network: Unheralded Structure in Current Conceptualizations of Family Functioning," pp. 247-254 in B. Neugarten (ed.), Middle Age and Aging. Chicago: The University of Chicago Press.

Sussman, M. 1970. "Family Relations and the Aged," pp. 300324 in A. Hoffman (ed.), The Daily Needs and Interests of older People. Springfield Ill: Charles C. Thomas Publisher.

Tissue, T. 1971. "Social Class and the Senior Citizen Center," Gerontologist 11:196-200.

Tobin, S., and B. Neugarten. 1961. "Life Satisfaction and Social Interaction in the Aging," Journal of Gerontology $16: 344-346$.

Troll, I. 1971. "The Family of Later Life: A Decade Review," Journal of Marriage and the Family 33:263290.

Vander Zanden, J. 1977. Social Psychology. New York: Random House.

Watson, A., and V. Kivett. 1976. "Influences on the Life Satisfaction of 01der Fathers," The Coodinator 25: $482-288$.

Weishaus, S. 1979. "Aging is a Family Affair," pp. 126174 in P. Ragon (ed.), Aging Parents. California: The University of Souther California Press.

Wood, V., M. Wylie, and B. Sheafor. 1969. "An Analysis of A Short Self-Report Measure of Life Satisfaction: Correlation with Rater Judgements," Journal of Gerontology $24: 465-489$. 
APPENDIX A

\section{INTRODUCTORY STATEMENT}

Dear Friends:

I am a graduate student at Portland State University working on my thesis for a master's degree in Sociology. The attached questionnaire is part of my research regarding satisfaction in your life and relationships with your adult or married children.

Your participation in this research is completely voluntary. However, your responses will be contributing to a better understanding of American family relationships and Iife satisfaction in general. Therefore, your answers are very important to this research because they represent hundreds of others which are not in the study.

There are no right or wrong answers in this questionnaire. Please check the response which is most applicable. Your responses will be strictly CONFIDENTIAL. The last page is self-addressed and stamped so that you can mail the completed questionnaire back to me at no expense to yourself. Please fold and tape or staple questionnaire for confidentiality.

Your help is greatly appreciated. If you have any questions regarding this research, please write to me:

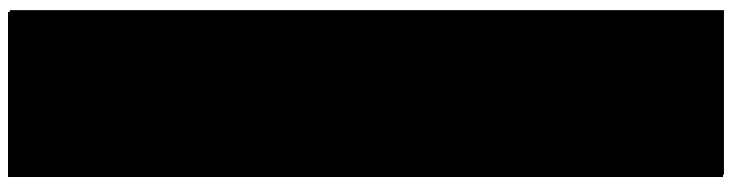




\section{Questionnaire}

Questions in this section are general information about you. Please answer every question. Thank you.

1. Date of birth:

3. Narital status:
2. Sex: male $4 \cdot$

2. Number of your living children

b. Number of your unmarried children over 21

c. Number of your married children of any age

6. a. How many other people live in this household with you?

b. What is their relationship to you? (e.g. husband, son, sister, friend, etc.)

\begin{tabular}{|c|c|c|c|c|c|c|c|c|}
\hline & $\begin{array}{l}\text { How often do you take } \\
\text { part in activities: }\end{array}$ & $\begin{array}{l}\text { more than } \\
\text { once a } \\
\text { week }\end{array}$ & weekly & $\begin{array}{l}2 \text { to } 3 \\
\text { times a } \\
\text { month }\end{array}$ & monthly & $\begin{array}{l}\text { several } \\
\text { times a } \\
\text { year }\end{array}$ & $\begin{array}{c}\text { once } \\
\text { year } \\
\text { less }\end{array}$ & never \\
\hline a. & of religious groups & & & & & & & \\
\hline b. & of senior center & & & & & & & \\
\hline & $\begin{array}{l}\text { of other clubs or } \\
\text { organizations }\end{array}$ & & & & & & & \\
\hline d. & $\begin{array}{l}\text { with relatives (e.g. } \\
\text { visiting, going out } \\
\text { to restaurant, etc.) }\end{array}$ & & & & & & & \\
\hline e. & $\begin{array}{l}\text { with neighbors or } \\
\text { friends (e.g. visit- } \\
\text { ing, shopping, etc.) }\end{array}$ & & & & & & & \\
\hline
\end{tabular}

\begin{tabular}{|c|c|c|c|c|c|c|}
\hline 8. & $\begin{array}{l}\text { Compared with others of your age, } \\
\text { how would you rate: }\end{array}$ & $\begin{array}{l}\text { very } \\
\text { good }\end{array}$ & good & fair & poor & $\begin{array}{l}\text { very } \\
\text { poor }\end{array}$ \\
\hline & a. your health? & & & & & \\
\hline & b. your financial situation? & & & & & \\
\hline
\end{tabular}


Part II:

The following are some statements about life in general that poople féel differently about. Would you read each statement on the list, and put a check mark in the space which you feel it is appropriate for you. If you are not sure one way or the other, put a check mark under "not sure." Please be sure to answer every question on the list.

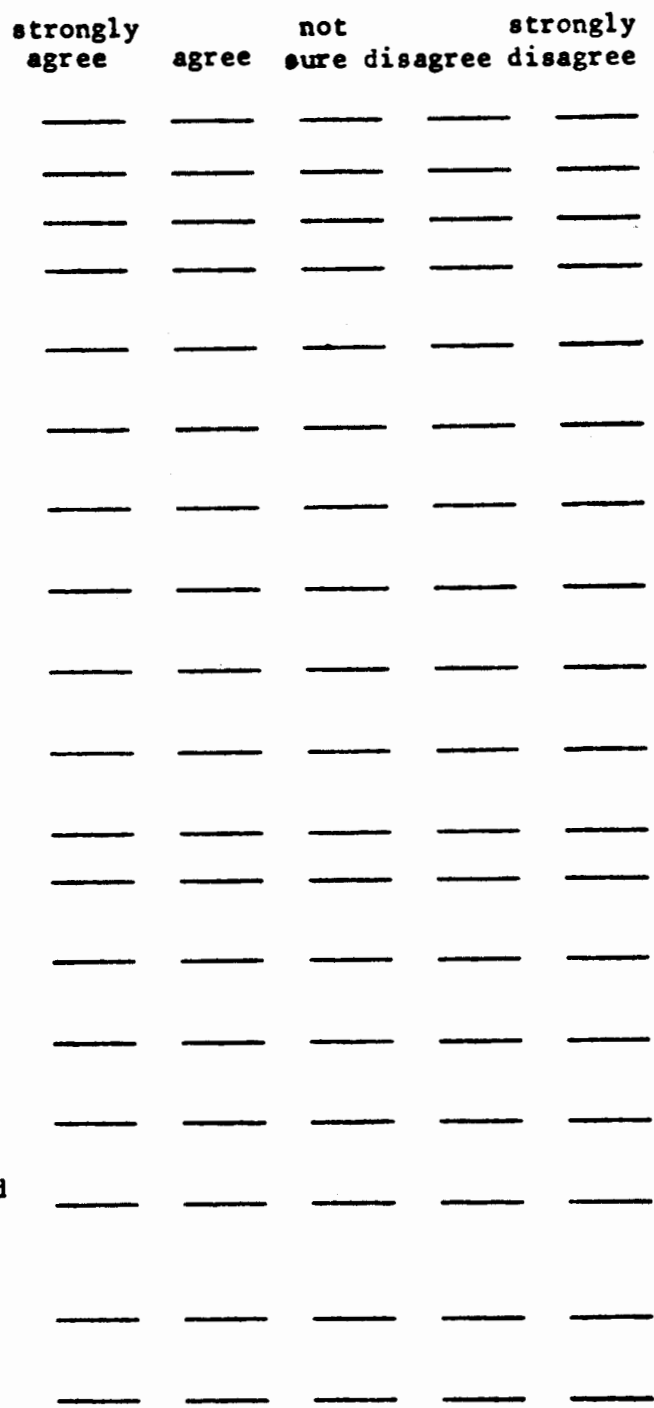

1. I am just as happy as when I was younger

2. These are the best years of my life

3. My life could be happier than it is now

4. This is the dreariest time of my life

5. Most of the things I do are boring and monotonous

6. Compared to other people, I get down in the dumpo too often

7. The things I do are as interesting to me as they ever were

8. I've made plans for things I'll be doing a month or a year from now

9. Compared to other people my age, I make a good appearance

10. As I grow older, things seem better than I thought they would be

11. I expect some interesting and pleasant things to happen to me in the future

12. I feel old and somewhat tired

13. As I look back on wy life, I am fairly well satisfied

14. I would not change my past life even if I could

15. I've gotten pretty much what I expected out of life

16. When I think back over my life, I didn't get mot of the important things I wanted

17. In spite of what people say, the lot of the average man is getting worse, not better

18. I've gotten more of the breaks in life than most of the people I know 
Part III:

Below are some statements regarding the relationship between parents and their adult children. Different people have different opinions on these statements. Please indicate your opinion by checking the appropriate answer. "Adult children" here means children who have reached the age of 21 or at any age who are married. Please answer every question.

1. Children should live with their parents

2. Children who do not 1 ive with their parents should live close to them

3. Children should be willing to give their parents financial help

4. Children should take care of their parents in whatever way necessary, when they are sick

5. If children live nearby, they should call their parents at least once a week

6. If children live nearby, they should visit their parents at least once a week

7. Children 1 iving at a distance should call their parents at least once a month

8. Children living at a distance should write to their parents at least once a month

9. Children should comfort their parents, when they are depressed

10. Children should respect their parents' opinions

11. Children should be willing to accept their parents' suggestions

12. One of the important reasons for having children is that parents will have their children to take care of them when they are old

strongly agree

agree

not

sure disagree disagree 
Part IV:

here are questions about activities and attitudes between you and your child(ren) in general. Please answer every question.

1. How many of your children:

live with you?

live in the same neighborhood?

live elsewhere in the Portland area?

live in some other part of Oregon?

live in another state?

live in another country?
2. Have any of your children done the following things?

a. helped out when

yes no you were sick?

b. tried to comfort you when you got depressed?

\begin{tabular}{|c|c|c|c|c|c|c|c|}
\hline $\begin{array}{l}\text { 3. When was the last } \\
\text { time your child(ren): }\end{array}$ & $\begin{array}{l}\text { yester- } \\
\text { day }\end{array}$ & $\begin{array}{l}\text { last } \\
\text { week }\end{array}$ & $\begin{array}{l}\text { last } \\
\text { month }\end{array}$ & $\begin{array}{l}\text { last } 6 \\
\text { months }\end{array}$ & $\begin{array}{l}\text { last } \\
\text { year }\end{array}$ & $\begin{array}{l}\text { more than a } \\
\text { year ago }\end{array}$ & never \\
\hline $\begin{array}{l}\text { a. gave you financial } \\
\text { help? }\end{array}$ & & & & & & & \\
\hline p. visited goù? & & & & & & & \\
\hline c. telephoned you? & & & & & & & \\
\hline d. wrote to you? & & & & & & & \\
\hline
\end{tabular}

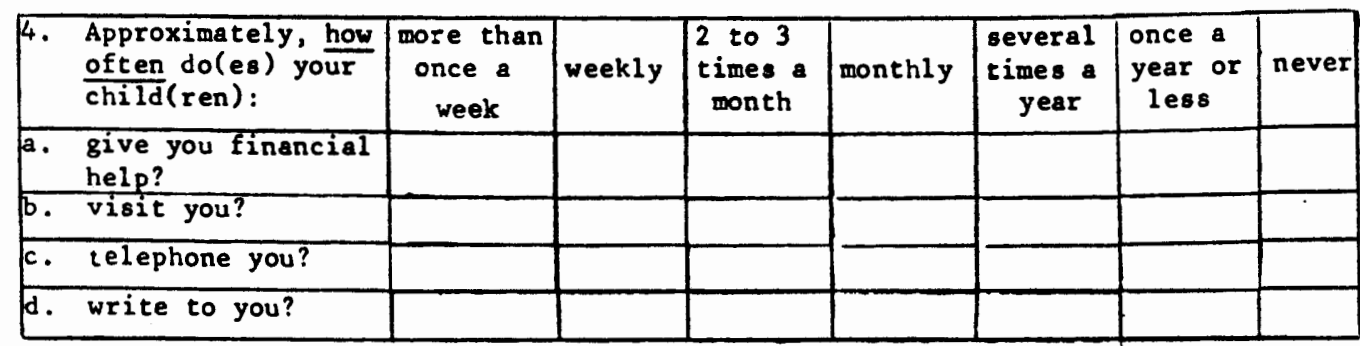

5. Your child(ren)'s attitude(s) toward your opinions is (are):

very respectful
respectful
fair
- disrespectful
very disrespectful

7. In general, how satisfied are you with the way your child(ren) treat you? very satisfied satisfied fair dissatisfied very dissatisfied
6. In general, when you make a suggestion to your child(ren), he or she (they) accepts your suggestion:

very often
often
sometimes


seldom
never




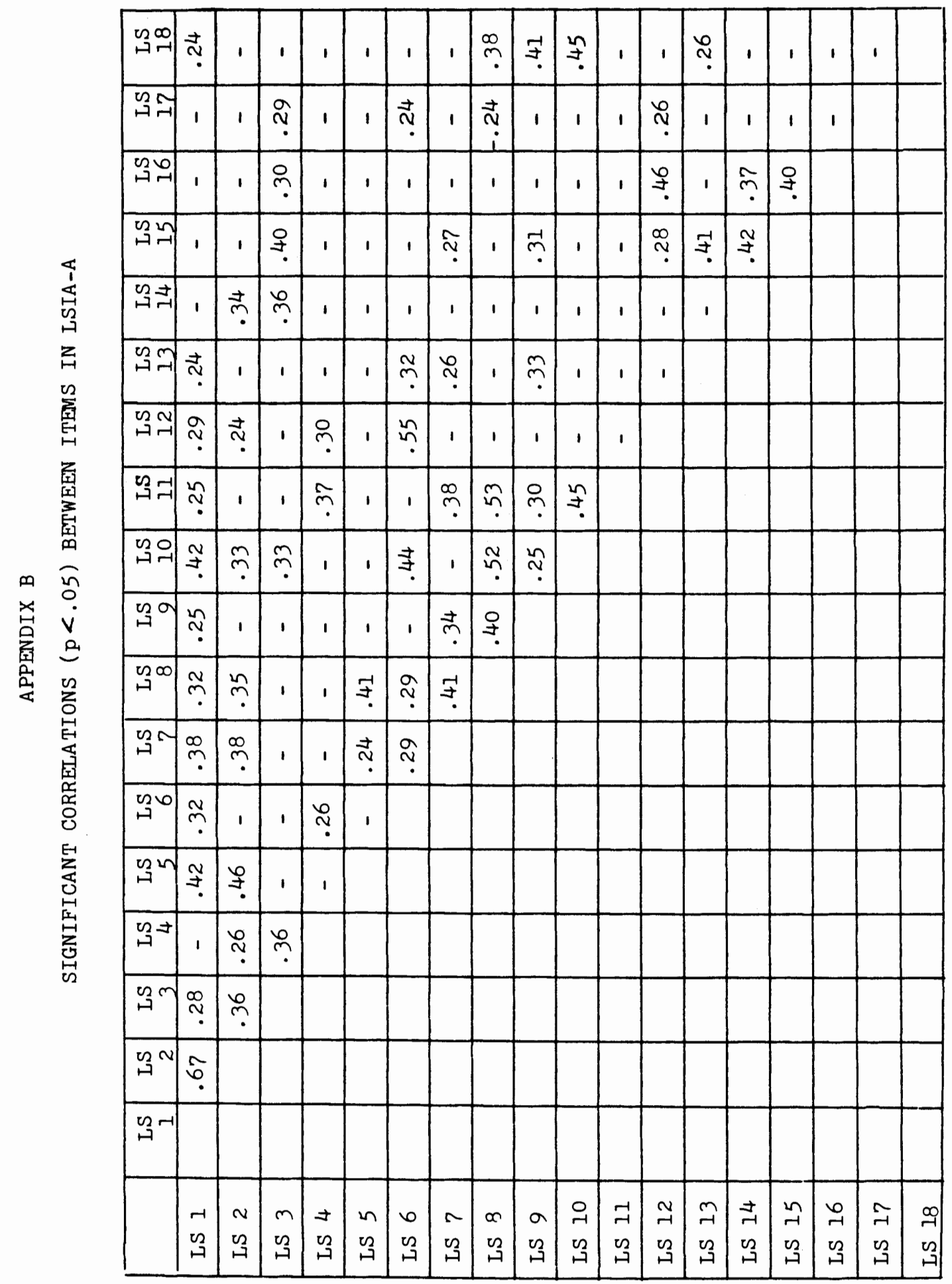




\section{APPENDIX B \\ (continued) \\ EXPLANATION OF LS 1 THROUGH LS 18}

LS I: I am just as happy as when I was younger

LS 2: These are the best years of my life

LS 3: My life could be happier than itis now

LS 4: This is the dreariest time of my life

LS 5: Most of the things I do are boring and monotonous

LS 6: Compared to other people, I get down in the dumps too often

LS 7: The things I do are as interesting to me as they ever were

IS 8: I've made plans for things I'll be doing a month or a year from now

IS 9: Compared to other people my age, I make a good appearance

LS10: As I grow older, things seem better than I thought they would be

LSII: I expect some interesting and pleasant things to happen to $m e$ in the future

LS12: I feel old and somewhat tired

LS13: As I look back on my life, I am fairly well satisfied

LSI 4: I would not change my past life even if I could

LS15: I've gotten pretty much what I expected out of life

LS16: When I think back over my life, I didn't get most of the important things I wanted

LSI7: In spite of what people say, the lot of the average man is getting worse, not better

LS18: I've gotten more of the breaks in life than most of the people I know 


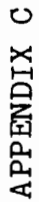

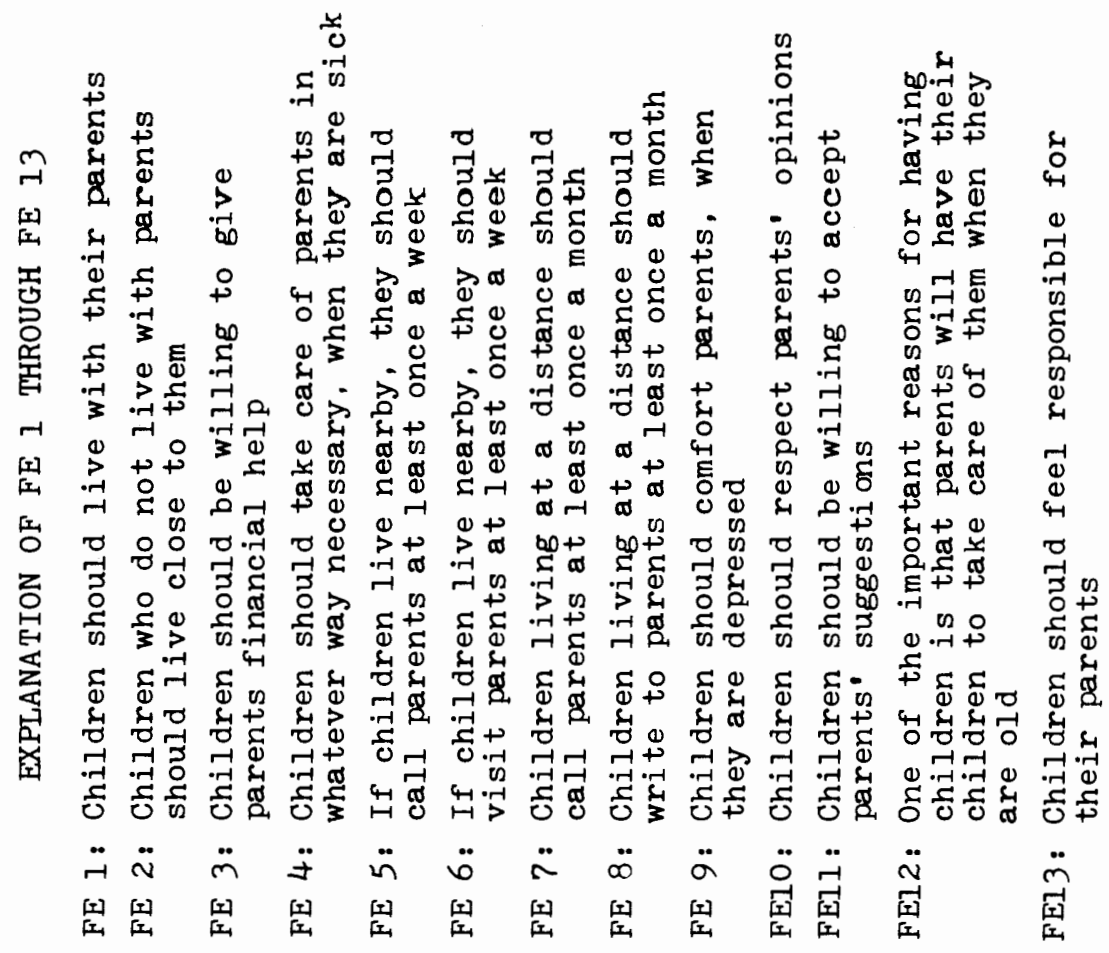

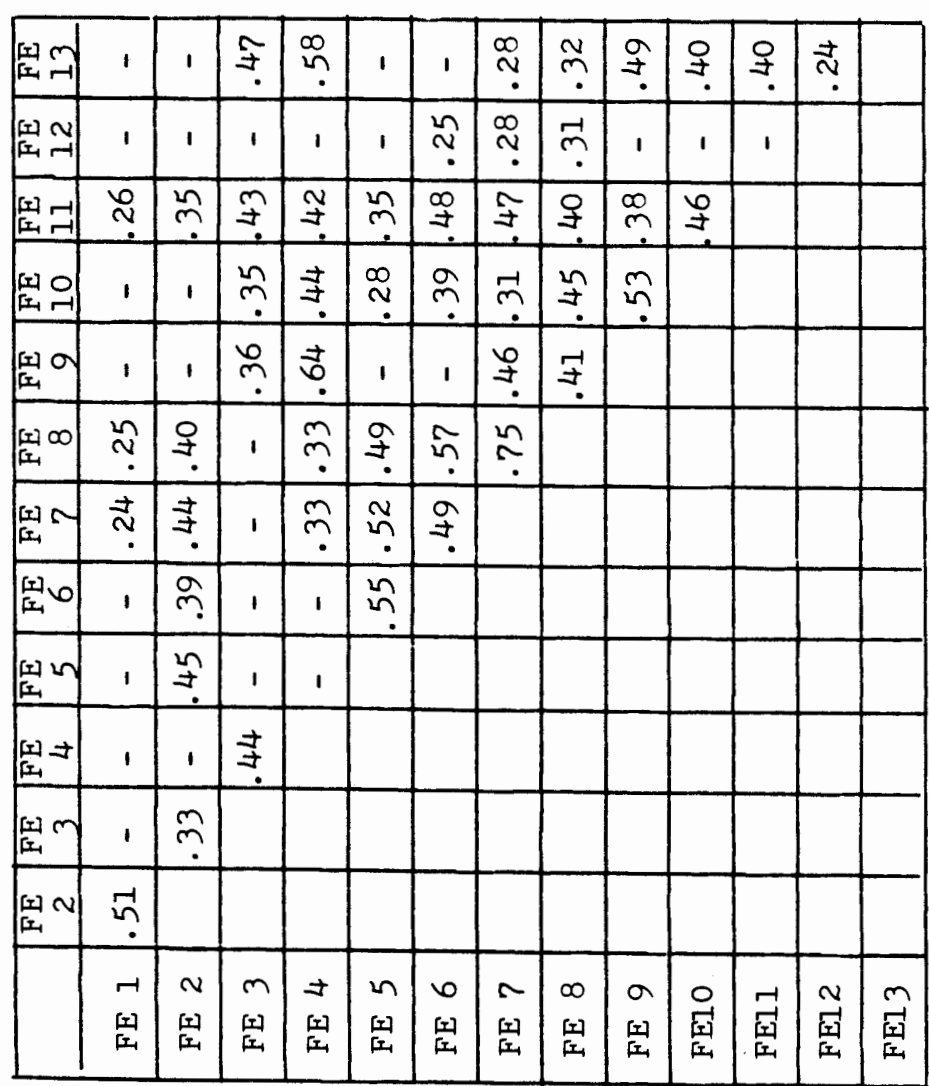




\begin{tabular}{|c|c|c|c|c|c|c|c|c|c|c|c|c|c|c|c|c|c|c|c|}
\hline & $\begin{array}{ll}m & 0 \\
\text { si } & -1\end{array}$ & 1 & 1 & 1 & 1 & 1 & 1 & n? & $\stackrel{m}{m}$ & 1 & 1 & $\stackrel{m}{\exists}$ & $\stackrel{\infty}{\ddagger}$ & 1 & $\stackrel{9}{9}$ & 寻 & $\stackrel{r-1}{n}$ & $\begin{array}{l}0 \\
?\end{array}$ & $\stackrel{N}{\rightleftharpoons}$ \\
\hline & {$\left[\begin{array}{ll}\infty & \infty \\
1 & \cdots\end{array}\right.$} & 1 & 1 & 1 & 1 & ํ. & 1 & 1 & 1 & $\tilde{m}$ & 1 & 1 & $\stackrel{n}{m}$ & $\stackrel{m}{m}$ & 1 & 1 & $\stackrel{o}{N}$ & n? & \\
\hline & 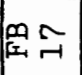 & 1 & $m$ & 1 & 1 & 1 & 1 & 1 & 1 & 1 & 1 & 1 & $\tilde{m}$ & 1 & $\stackrel{n}{m}$ & 1 & 1 & & \\
\hline & 番 & 1 & 1 & 1 & 1 & 1 & 1 & $\stackrel{\circ}{\stackrel{0}{*}}$ & $\tilde{m}$ & 1 & 1 & 1 & g. & 1 & 1 & 1 & & & \\
\hline 占 & $\begin{array}{ll}n & n \\
x & 10\end{array}$ & 1 & กี่ & 1 & 1 & $\stackrel{n}{m}$ & 1 & $\stackrel{N}{\exists}$ & 1 & 1 & $\hat{b}$ & $\vec{Z}$ & $\mathbf{I}$ & 1 & $\stackrel{0}{尺}$ & & & & . \\
\hline $\begin{array}{l}n \\
2 \\
2\end{array}$ & $\stackrel{m}{a} \underset{\sim}{\sim}$ & 1 & 는 & $\stackrel{n}{N}$ & 1 & $\stackrel{n}{m}$ & 1 & $\widehat{N}$ & 1 & 1 & $\stackrel{\infty}{\infty}$ & $\begin{array}{l}\infty \\
\stackrel{n}{?}\end{array}$ & 1 & $\stackrel{৩}{N}$ & & & & & \\
\hline $\begin{array}{l}\stackrel{H}{\mapsto} \\
z\end{array}$ & 昰 & $\stackrel{v}{v}$ & 1 & 1 & 1 & 1 & $\rightrightarrows$ & 1 & 1 & वू. & $\stackrel{v}{m}$ & 1 & 1 & & & & & & \\
\hline 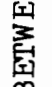 & 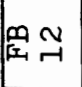 & 1 & 1 & 1 & 1 & $\stackrel{\sim}{\exists}$ & 1 & $\stackrel{v}{?}$ & $\stackrel{9}{9}$ & 1 & 1 & 1 & & & & & & & \\
\hline ñ & 鼠 & 1 & $\stackrel{\infty}{m}$ & 1 & 1 & 1 & 1 & ○ & $\ddot{n}$ & 1 & ำ & & & & & & & & \\
\hline $\begin{array}{l}V \\
\Omega^{2}\end{array}$ & 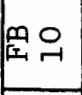 & 1 & $\stackrel{\infty}{m}$ & $\stackrel{\sim}{\leftrightarrows}$ & $\stackrel{o}{v}$ & n & 1 & 1 & 1 & 1 & & & & & & & & & \\
\hline$\stackrel{2}{2}_{0}^{2}$ & ma & 1 & 1 & 1 & 1 & 1 & $\stackrel{\vec{m}}{?}$ & 1 & 1 & & & & & & & & & & \\
\hline 茎 & $m_{1} \infty$ & $\stackrel{v}{v}$ & $\stackrel{\circ}{\dddot{m}}$ & $\vec{\sim}$ & 1 & $\stackrel{N}{m}$ & 1 & ก & & & & & & & & & & & \\
\hline 0 & $m_{1-1} \Omega$ & 1 & 1 & I & 1 & 1 & 1 & & & & & & & & & & & & \\
\hline 坛 & ar & 1 & 1 & 1 & 1 & 1 & & & & & & & & & & & & & \\
\hline 黍 & $\omega_{1} n$ & 1 & 1 & 1 & 1 & & & & & & & & & & & & & & \\
\hline & $m_{1}=$ & 1 & 1 & 1 & & & & & & & & & & & & & & & \\
\hline & $m_{m} m$ & 1 & 1 & & & & & & & & & & & & & & & & \\
\hline & $\mid l_{i} N$ & 1 & & & & & & & & & & & & & & & & & \\
\hline & & $\vec{r}$ & $\begin{array}{l}w \\
p \\
q\end{array}$ & $\begin{array}{l}m \\
m \\
m\end{array}$ & $\begin{array}{l}\Rightarrow \\
m \\
q\end{array}$ & n & $\begin{array}{l}0 \\
m \\
q\end{array}$ & 品 & $\begin{array}{l}\infty \\
\infty \\
\infty\end{array}$ & $\begin{array}{l}a \\
p \\
q\end{array}$ & $\begin{array}{l}0 \\
\stackrel{0}{-1} \\
\text { 寽 }\end{array}$ & 点 & $\begin{array}{c}N \\
\stackrel{n}{a}\end{array}$ & $\begin{array}{l}m \\
\text { pr } \\
\text { pr. }\end{array}$ & 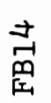 & 年 & $\begin{array}{l}0 \\
\stackrel{1}{1} \\
\text { pr } \\
\text { I. }\end{array}$ & 菸 & 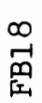 \\
\hline
\end{tabular}




\section{APPENDIX D}

(continued)

EXPLANATION OF FB I THROUGH FB 19

FB I: Children live with parents

FB 2: Children live in the same neighborhood as parents do

FB 3: Children live in the Portland area

FB 4: Children live in other part of Oregon

FB 5: Children live in another state

FB 6: Children live in another country

FB 7: Children have helped out parents when they were sick

FB 8: Children have tried to comfort parents when they got depressed

FB 9: Last time children gave financial help to parents

FBI0: Last time children visited parents

FBIl: Last time children telephoned parents

FB12: Last time children wrote to parents

FBI3: Frequency of children's financial help

FB14: Frequency of children's visit

FB15: Frequency of children's phone call

FB16: Frequency of children's letter

FBI7: Children's attitudes toward parents' opinions

FBI 8: Children's conformity to parents' suggestions

FB19: Parents' satisfaction with children's treatments 